\title{
Medicinal Plants for Treatment of Cancer: A Brief Review
}

\author{
Sonika Jain, ${ }^{1}$ Jaya Dwivedi ${ }^{1}$, Pankaj Kumar Jain ${ }^{2}$, Swaha Satpathy ${ }^{3}$ and Arjun Patra ${ }^{3 *}$ \\ 'Department of Chemistry, Banasthali Vidyapith, Rajasthan, INDIA. \\ 2Department of Pharmacy, Banasthali Vidyapith, Rajasthan, INDIA. \\ 3Institute of Pharmacy, Guru Ghasidas Vishwavidyalaya, Bilaspur (C.G.), INDIA.
}

\begin{abstract}
Cancer is actually a group of many related diseases that all have to do with cells. Cancer cells are characterized by unregulated growth, as well as insufficient and inappropriate vascular supply. Moreover, a core of cells was subjected to micro environmental stress conditions, and has decreased apoptotic potential through genetic alterations, thereby resulting in resistance to apoptosis. Cancer is one of the major causes of death worldwide where the number of cancer patients is in continuous rise. Cancer is a major public problem whose estimated worldwide new incidence is about 6 million cases per year. It is the second major cause of deaths after cardiovascular diseases. Chemotherapy remains the principal mode of treatment for various cancers. A number of synthetic anticancer drugs are available in practice, but the side effects and the drug interactions are major drawbacks in its clinical utility. Most of the currently used chemotherapy drugs for cancers are known to develop resistance, exhibit non-selective toxicity against normal cells and restrict by dose-limiting side effects. Hence, cancer treatment and development of drugs for this disease remains a major clinical challenge. On the other hand, plants are an exceptionally viable source of biologically active natural products which may serve as commercially significant entities in themselves or which may provide lead structures for
\end{abstract}

the development of modified derivatives possessing enhanced activity and/or reduced toxicity in traeatment of cancer. Herbal medicines are now attracting attention as potential sources of anticancer agents and are widely used due to availability of the materials, affordability, relatively cheap and little or no side effects, wide applicability and therapeutic efficacy which in turn has accelerated the scientific research. For these reasons, World Health Organization (WHO) supports the use of traditional medicines which are efficacious and non toxic. In this review we have summarized few plants having anticancer activity.

Key words: Cancer, Medicinal Plants, Breast Cancer, Chemotherapy, Allopathic Drugs, Cancer Cell Lines.

Correspondence:

Dr. Arjun Patra, Assistant Professor Institute of Pharmacy, Guru Ghasidas Vishwavidyalaya, Koni, Bilaspur- 495009, Chhattisgarh, INDIA.

Phone no: 07752260027 ; Mob no: +917587471798

E-mail: drarjunpatra22@gmail.com

DOI: $10.5530 /$ pj.2016.2.1

\section{INTRODUCTION}

Our body is composed of many millions of tiny cells, each a selfcontained living unit. Normal cells in the body grow and divide for a period of time and then stop growing and dividing. Thereafter, they only reproduce themselves as necessary to replace defective or dying cells. Cancer occurs when this cellular reproduction process goes out of control. The abnormal growth and division observed in cancer cells is caused by damage in these cells DNA (genetic material inside cells that determines cellular characteristics and functioning). There are a variety of ways that cellular DNA can become damaged and defective. For example, environmental factors (such as exposure to tobacco smoke) can initiate a chain of events that results in cellular DNA defects that lead to cancer. Alternatively, defective DNA can be inherited from your parents. As cancer cells divide and replicate themselves, they often form into a clump of cancer cells known as a tumor. Tumors cause many of the symptoms of cancer by pressuring, crushing and destroying surrounding non-cancerous cells and tissues. ${ }^{1}$

Treatment options, which depend on the stage and type of cancer, include: Surgery, Radiation therapy, Chemotherapy, Biological therapy, Hormone therapy etc. Despite substantial improvements in the current treatments that are available for patients diagnosed with cancer and the positive influence of these treatments on survival, chemotherapy or radiation therapy cause an array of traumatic side effects, chemotherapy can sometimes cause unpleasant side effect like such as fatigue, sleep disturbance, appetite loss, hair loss, sore mouth, changes in taste, fever and infection, anxiety, depression, nausea, and vomiting. These side effects are often difficult to ameliorate or manage, and can significantly impair a cancer patient's quality of life (QOL). There are also chances of other harmful effects of these treatment viz. second cancers after chemotherapy, hormonal and reproductive problems, effects on the immunologic system, heart disease, effects on kidney and urinary bladder, effects on gastrointestinal organs, neurologic and psychological changes etc. ${ }^{2,3}$ Complementary and alternative therapies which do not use known cancer drugs, or use approaches not common in the medical community are so commonly used to control symptoms, that they are really mainstream approaches. It is important to research and understand the risks and benefits of these therapies.

\section{Advantages of herbal drugs over allopathic drugs}

Medicinal plants continue to play a central role in the healthcare system of large proportions of the world's population. Recognition and development of the medicinal and economic benefits of plants are on the increase in both developing and industrialized nations. An herb (also called a botanical) is a plant or plant part used for its scent, flavor, and/ or therapeutic properties. Products made from botanicals that are used to maintain or improve health have been called herbal supplements, botanicals, or phytomedicines. The pharmacological treatment of disease began long ago with the use of herbal medicines are "crude drugs of vegetable origin utilized for the treatment of disease states, often of a chronic nature, or to attain or maintain a condition of improved health" or the herbal medicines can be defined as "Finished labeled medicinal products that contain ingredients from aerial or underground parts of plant parts or other plant material or combination in the crude state or as plant preparations. It has been estimated that these medicines derived from plants constitute about 25 percent in modern pharmacopoeia. Traditional herbal medicines are naturally occurring plant-derived substances with minimal or no industrial processing that have been used to treat illness within local or regional healing practices. Common reasons for use of herbal drugs include health promotion, disease prevention, poor outcomes and limited treatment options for a serious illness, exhaustion of conventional therapies, dissatisfaction with, or lack of efficacy of conventional therapies, significant side effects or risks associated with conventional medicine, belief that herbal and natural products are better or safer, preference for personal involvement in the 
decision-making process, and cultural or spiritual preference. Whereas side effects of allopathic medications vary wildly from mild to severe and there are many. They include insomnia, vomiting, fatigue, dry mouth, diarrhea, constipation, dizziness, suicidal thoughts, hostility, depression, mania, seizures, coma, anemia, hair loss, high blood sugar, shoplifting, swelling, impotency, panic attacks, confusion, fainting and death. It is often difficult for seniors to keep track of multiple medications which further increase likelihood of side effects due to allopathic medicines. Drugs or surgery are often the primary treatments for a health condition when using allopathic medicine. Since drugs don't usually cure, but suppress and change the way the body functions, this covers up the condition instead of curing it. Sometimes this may be helpful (like with severe pain), but little or nothing may be done to improve the actual condition. Patients who would be good candidates for alternative therapy aren't given that opportunity. Drugs, surgery, hospitalizations and other medical procedures can cause adverse reactions, including death. Serious infections are a major risk when someone is hospitalized. Properly prescribed medications kill over 100,000 people in the U.S. alone. Another hundred thousand die from accidental overdose or prescribing errors. ${ }^{4}$

\section{Medicinal plants having anticancer potential}

\section{Adiantum venusutum}

Adiantum venusutum (Adiantaceae) is traditionally very useful in treating tumour. The phytochemicals, terpenoids, phytosterols, flavanoids and saponins are obtained from the petroleum ether and ethanolic extract of leaves and stem of Adiantum venusutum; and screened for the anticancer activity on Ehrlich Ascites Carcinoma in animals by using dose of 150-250 mg/kg. Ethanolic extract of A. venustum Don. (EEAV) exhibited significant anticancer and antioxidant activity due to its higher triterpenoids and flavonoids content. It is also found that EEAV significantly reduced the elevated levels of lipid peroxidation and thereby it acts as an antitumour agent. EEAV did not show any mortality up to the dose of $2000 \mathrm{mg} / \mathrm{kg}$. Aerial parts of $A$. venustum resulted in the isolation of normethyl lupine- type and lanostane type triterpenes. The structures of these triterpenes have been established as 30-normethyl lupine-20-one, 30-normethyl olean-3-one-30-betol, and lanost-20(22)ene-30-ol, on the basis of spectral data analyses. A triterpenic ether, lanost-20(22)-en-3, 19-ether, named adiantulanostene ether was isolated from A. venustum. ${ }^{5,6}$

\section{Abelmoschus moschatus}

The antiproliferative activities of ethanolic and aqueous extracts of Abelmoschus moschatus (Malvaceae) seed (AMS) and Abelmoschus moschatus leaf (AML) against two human cell lines-Colorectal adenocarcinoma (COLO-205) and retinoblastoma (Y79) were investigated. Flavanoids are responsible for the antiproliferative activty of the extract. The antiproliferative activity of seed (AMS-IV) and leaf (AML-IV) extracts of $A$. moschatus on the growth of cell lines in vitro was found at the concentration of $200 \mu \mathrm{g} / \mathrm{mL}$. The aqueous overnight seed extract (AMS-I) has shown significant antiproliferative activity by radical scavenging activity in 1,1-Diphenyl-2-picrylhydrazyl (DPPH), hydrogen peroxide, hydroxyl radical, superoxide and lipid peroxidation. ${ }^{7}$

\section{Aspidosperma tomentosum}

The antiproliferative activity terpenoids and alkaloids obtained from crude dicloromethane (CHD) and crude hydroalcoholic extract (CHE) extracts of Aspidosperma tomentosum (Apocynaceae) twigs and aerial part was found against five human cells line: K562 (leukemia), MCF7 (breast), NCIADR (breast expressing the multidrug resistance phenotype), NCI460 (lung) and UACC62 (melanoma), in a concentrationdependent way. The extracts were tested in concentration between 15.6 and $125 \mu \mathrm{g} / \mathrm{ml}$ and a concentration dependent inhibition was observed for both crude extracts on MCF7, UACC62, NCIADR and NCI460. However, an important cytocidal activity (46\%) was observed for MCF7 when CHD at 125 was tested.

\section{Anemopsis californica}

Three different extract conditions (aqueous, EtOH and EtOAc) of four different parts (bracts, leaves, roots and stems) of Anemopsis californica (Saururaceae) were evaluated for their effect on the growth and migration of human colon cancer cells, HCT-8, and the breast cancer cell lines Hs 578T and MCF-7/AZ. The dose upto $200 \mu \mathrm{g} / \mathrm{ml}$ was taken and found non toxic to the viability of the other cells. Essential oil components monocyclic (cymene, limonene, piperitone and thymol) and bicyclic ( $\alpha$-pinene, myrtenol and 1,8-cineole) monoterpenoid and phenylpropanoid (methyleugenol, isoeugenol and elemicin) derived from the methanolic extract of roots and rhizomes of $A$. californica demonstrated anti-proliferative activity against $\mathrm{AN} 3 \mathrm{CA}$ and $\mathrm{HeLa}$ cells in vitro. The $\mathrm{IC}_{50}$ values for the root oil were $0.056 \%$ and $0.052 \%(\mathrm{v} / \mathrm{v})$ for the AN3CA and HeLa cells respectively. The concentration of these oils $\alpha$-pinene (1.9\%), $\beta$-phellandrene (1.6\%), 1,8-cineole (2.5\%), piperitone $(11.5 \%)$, methyleugenol (6.9\%), (E)-caryophyllene (4.6\%) and elemicin $(53 \%)$ have anticancer activity. In plant roots methyleugenol comprised 55\% of the root oil, with thymol at $13 \%$ and piperitone at $5 \% .{ }^{9-11}$

\section{Alangium salviifolium}

The phytoconstituents like sterols, glycosides, saponins, carbohydrates, alkaloids, flavonoids, tannins, proteins and triterpenoids are identified in the ethanolic, chloroform, alcohol and distilled water extract of Alangium salviifolium (AS) [Cornaceae (Alangiaceae)] seeds, flowers, roots and leaves showed significant antitumor activity against Ehrlich Ascites Carcinoma (EAC) in mice at the doses of $10 \mathrm{mg} / \mathrm{kg}$ body weight intraperitoneally. The anticancer activities of chloroform extract of A. salvifolium are probably due to the presence of alkaloid, phenolic compounds, flavonoids as well as terpenoids. Flavanoids such as quercitin, kaemferol and their glycosides showed anticancer activity. They also alter signal transduction in pathways leading to tumor growth and stimulate apoptosis in tumor cell lines. They have shown to enhance in vitro human peripheral blood lymphocyte and T-cell proliferation. ${ }^{12-14}$

\section{Acorus calamus}

Several essential oils bioactive compounds like $\beta$-asarone (46.78\%), linalool (0.41), farnesol (11.09\%), methyleugenol (6.10\%), $\alpha$ - and $\beta$-pinene (both $0.06 \%)$, [E]-caryophyllene $(0.11 \%), \beta$-elemene $(0.39 \%)$, ocimene $(0.7 \%)$, aromadendrene $(0.26 \%)$, camphor $(0.03 \%)$, from Acorus calamus (Araceae) were identified for the antitumor activity and assayed in MDA-MB-435S and Hep3B cell lines. The plant possesses anti-tumor properties at the dose of $30 \mu \mathrm{g} / \mathrm{ml}$. Sesquiterpenes, phenylpropanoid etc. are isolated from of the ethanolic extract of $A$. calamus rhizomes and were evaluated for anticancer activity. The ethanolic extract of $A$. calamus dried aerial part showed antiproliferative activity at dose of $250-500 \mathrm{mg} / \mathrm{kg}$. A. calamus also shows effect on nickel chloride $\left(\mathrm{NiCl}_{2}\right)$-induced renal oxidative stress, toxicity, and cell proliferation response in male wistar rats. $\mathrm{NiCl}_{2}(250 \mu \mathrm{mol} / \mathrm{kg}$ body weight $/ \mathrm{mL})$ enhanced reduced renal glutathione content (GSH), glutathioneS-transferase (GST), glutathione reductase (GR), lipid peroxidation (LPO), $\mathrm{H}_{2} \mathrm{O}_{2}$ generation, Blood urea nitrogen (BUN), and serum creatinine with a concomitant decrease in the activity of glutathione peroxidase (GPx) $(\mathrm{p}<0.001) . \mathrm{NiCl}_{2}$ administration also dose-dependently induced the renal ornithine decarboxylase (ODC) activity several-folds as compared to saline treated control rats. ${ }^{15-19}$

\section{Antiaris africana}

The methanol extract from the stem bark of Antiaris africana (Moraceae) as well as compounds isolated and identified as betulinic acid, 
$3 \beta$-acetoxy-1 $\beta, 11 \alpha$-dihydroxy-olean-12-ene, ursolic acid, oleanolic acid, strophanthidol, periplogenin, convallatoxin, strophanthidinic acid, methyl strophanthinate, and 3, 39-dimethoxy-49-O- $\beta$-d-xylopyronosyl ellagic acid, were tested for their anticancer activities against DU-145 and Hep G2 cells. Extract showed the highest inhibition potency on both cell lines at $30 \mu \mathrm{g} / \mathrm{mL}$. From the extract two new bioactive metabolites were isolated, amyrin (antiarol cinnamate) and a cardiac glycoside, $3 \beta$-O-( $\alpha$-L-rhamnopyranosyl)-14 $\beta$-hydroperoxy-5 $\beta$-h which have selective antitumor activity against human tumor cell lines. Africanoside effected a concentration-dependent inhibition of tumor cell growth with a mean $\mathrm{IC}_{50}$ value of $5.3 \mathrm{nM} .^{20,21}$

\section{Amoora rohituka}

Amooranin (AMR), a triterpene acid isolated from the petroleum ether, dichloromethane, and ethanol fraction of stem bark of Amoora rohituka (Meliaceae). The mechanism of cell death associated with AMR cytotoxicity in human mammary carcinoma MCF-7, multidrug resistant breast carcinoma MCF-7/TH and breast epithelial MCF-10A cell lines. $\mathrm{AMR} \mathrm{IC}_{50}$ values ranged between 3.8-6.9 $\mu \mathrm{g} / \mathrm{ml}$ among MCF-7, MCF-7/ $\mathrm{TH}$ and MCF-10A cells. The induction of apoptosis in AMR treated cells was accompanied by the elevation of total caspase and caspase- 8 activities. AMR induced caspase-8 activation in 40.8-71\% MCF-7, 28.5-43.2\% MCF-7/TH and $4-32.8 \%$ MCF-10A cells at $1-8 \mu \mathrm{g} / \mathrm{ml}$ concentrations. Its ability to overcome multidrug resistance in human leukemia and colon carcinoma cell lines was defined. AMR $\mathrm{IC}_{50}$ values of multidrugresistant leukemia (CEM/VLB) and colon carcinoma (SW620/Ad-300) cell lines were higher (1.9- and 6-fold) than parental sensitive cell lines (CEM and SW620). These fractions were explored for their anticancer potential against two breast cancer (MCF-7 and HTB-126) and three pancreatic cancer (Panc-1, Mia-Paca2, and Capan1) also. An ethyl acetate extract derived from the stem bark of $A$. rohituka exhibited antitumor activity on mice inoculated with Dalton's lymphoma ascites cells (DLA). Intraperitoneal administration of the extract at doses of 10 or $20 \mathrm{mg} / \mathrm{kg} /$ day prolonged the median survival time of the animals. It showed cytotoxicity against Dalton's lymphoma ascites cells with a $50 \%$ inhibitory concentration $\left(\mathrm{IC}_{50}\right.$ ) of $9 \mu \mathrm{g} / \mathrm{ml}$. Methyl-25-hydroxy3-oxoolean-12-en-28-oate (AMR-Me) is a novel semisynthetic triterpenoid, derived from a triterpene acid isolated from the stem bark of a tropical tree Amoora rohituka. AMR-Me inhibited the growth and viability of CEM cells, induced apoptosis and cell cycle arrest in $\mathrm{G}_{2}{ }^{+} \mathrm{M}$ phase and displays breast carcinoma MDA-468, breast adenocarcinoma MCF-7 cells compared to breast epithelial MCF-10A control cells. AMR-Me treatment resulted in suppression of hTERT expression and a concomitant inhibition of telomerase activity. For HTB126, Panc-1, Mia-Paca2, and Capan-1 cancer cells, the $\mathrm{CH}_{2} \mathrm{Cl}_{2}$ extract of dried whole plant showed a significant cytotoxic effect. ${ }^{22-28}$

\section{Arnebia nobilis}

Beta-dimethyl acryl shikonin from the root of Arnebia nobilis (Boraginaceae) possess anti-cancer activity by blocking of cell cycle progression in G1 phase, decreased expression of Cyclin D, CDK 4 and PCNA, inhibition of bcl2 expression at transcriptional level and induction of caspase- 3 activity. Arnebin isolated from the roots of $A$. nobilis, inhibits rat walker carcinosarcoma, but activity was not found in the leaves and the stem. ${ }^{29}$

\section{Aesculus hippocastanum}

Recent studies in vivo and in vitro indicate that aescin ( $\beta$-escin) has significant antitumor activities. $\beta$-escin from $A$. hippocastanum (Sapindaceae) inhibited chemically induced colon carcinogenesis in rats, and in vitro exhibited cytotoxicity at $30 \mu \mathrm{mol} / \mathrm{L}$ or above concentrations in colon cancer cell lines. $\beta$-escin at $5 \mu \mathrm{mol} / \mathrm{L}$ also inhibited HT-29 colon cancer cell proliferation. $\beta$-escin induced cell cycle arrest at G1-S phase in part mediated by induction of p21WAF1/CIP1 and/or associated with reduced levels of Cdk2 and cyclins $\mathrm{A}$ and E complex. ${ }^{30}$

\section{Aegle marmelos}

The hydroalcoholic leaf extract of Aegle marmelos (AME) (Rutaceae) was studied in the Ehrlich ascites carcinoma bearing Swiss albino mice and anticancer activity is due the presence of skimmianine in the extract. Butylp-tolyl sulfide, 6-methyl-4-chromanone and 5-methoxypsoralen were isolated from the extracts of Aegle marmelos is able to inhibit the in vitro proliferation of human tumor cell lines, including the leukemic K562, T-lymphoid Jurkat, B-lymphoid Raji, erythroleukemic HEL, melanoma Colo38, and breast cancer MCF7 and MDA-MB-231 cell lines. The acute toxicity study of AME showed that the drug was non-toxic up to a dose of $1750 \mathrm{mg} / \mathrm{kg}$ b. wt. An endophytic fungus Bartalinia robillardoides (strain AMB-9) isolated from the organic extract of bark, leaves and roots of $A$. marmelos, responsible for taxol production, has strong cytotoxic activity towards BT 220, H116, Int 407, HL 251 and HLK 210 human cancer cells in vitro. The amount of taxol produced by this fungus in liquid culture was $187.6 \mathrm{lg} / \mathrm{L}$. The molecule 1-hydroxy-5,7-dimethoxy-2-naphthalene-carboxaldehyde (HDNC, marmelin) was isolated from ethyl acetate fraction of extracts of A. marmelos, activates apoptosis of epithelial cancer cells through activation of tumor necrosis factor- $\alpha$ (TNF- $\alpha$ ), TNF receptor (TNFR)associated death domain (TRADD), and caspases with induces apoptosis during $\mathrm{G}_{1}$ phase of the cell cycle. A. marmelos methanolic extract has inhibitory effects on diethylnitrosamine (DEN) initiated and 2-acetyl aminofluorene (2-AAF) promoted liver carcinogenesis in male wistar rats. It was found that $A$. marmelos ( 25 and $50 \mathrm{mg} / \mathrm{kg}$ body weight) resulted in a marked reduction of the incidence of liver tumors. ${ }^{31-35}$

\section{Allium sativum}

The anti-cancer activity of garlic-derived organosulfur compounds (OSCs) originating from aqueous extract (GAE) of aerial part and bulbs of Allium sativum (Alliaceae) cause cell cycle arrest, inhibit cancer (HeLa) cell line and generate reactive oxygen species (ROS). In addition inhibition of lymphocyte proliferation was observed in the presence of higher concentrations of GAE. The garlic derivative $S$-allylmercaptocysteine (SAMC) inhibits growth, arrests cells in $\mathrm{G}_{2}-\mathrm{M}$, and induces apoptosis in human colon cancer cells by thus arresting cells in mitosis and triggering JNK1 and caspase-3 signaling pathways that lead to apoptosis. Allicin, a major component of garlic has antitumoral activity in L5178Y lymphoma bearing mice. Intact garlic cloves also contain steroidal saponins and organic selenium compounds that possess a potential anticancer efficacy. The main selenium compound is $\gamma$-glutamylS-methylselenocysteine. Ajoene is one of the main compounds formed from heating crushed garlic has cytotoxicity towards cancer cells is postulated to occur via an apoptotic mechanism involving activation of the mitochondrial-dependent caspase cascade. The dose of $5 \mu \mathrm{g} / \mathrm{animal}$ is effective on the antitumor activity. Methanolic extract of $A$. sativum (MEAS) possesses anticancer activity in MCF7, A549 \& DU145 and cell carcinoma of the bladder. Cytotoxic effects of a lectin prepared from A. sativum bulbs on human tumor cells reduced the growth and DNA synthesis of human tumor cells in a time- and a dose-dependent manner. Sesquiterpene lactones (SLs) have been demonstrated to execute their anticancer capability via inhibition of inflammatory responses, prevention of metastasis and induction of apoptosis. Thirdly, the molecular mechanism involved in the anticancer activity of SLs, in particular, the SL-thiols reaction, the effect of SLs on cell signaling pathways such as nuclear transcription factor-kappaB (NF-kappaB) and mitogen-activated protein kinases (MAPK). ${ }^{36-39}$ 


\section{Biophytum sensitivum}

An alcoholic extract of Biophytum sensitivum (Oxalidaceae) leaves was also found to be cytotoxic towards L929 cells in culture at a concentration of $0.1 \mathrm{mg} / \mathrm{ml}$. The extract was $100 \%$ toxic at a concentration of $0.5 \mathrm{mg} / \mathrm{ml}$ to Dalton's lymphoma ascites (DLA) and Ehrlich ascites carcinoma (EAC) cells. Incubation of B16F-10 cells with B.sensitivum showed the presence of apoptotic bodies and induced DNA fragmentation. B. sensitivum inhibited the expression of MMP-2 and MMP-9, whereas it activated STAT-1 expression in metastatic tumor-bearing lungs. $B$. sensitivum treatment also downregulated the expression of tumor necrosis factor- $\alpha$, interleukin (IL)-1 $\beta$, IL-6, and granulocyte monocyte-colony stimulating factor in metastatic tumor-bearing lungs. The antitumor effects of aqueous extract of $B$. sensitivum (AEBS) leaves at the doses of 100 and $200 \mathrm{mg} / \mathrm{kg} \mathrm{b}$. wt, in mice for 28 days after $24 \mathrm{~h}$ of tumor was studied against Dalton's Ascitic Lymphoma (DAL) bearing Swiss albino mice. $B$. sensitivum has been shown to contain biflavones and flavanoids compounds which are responsible for the antitumor activity produced by this extract. B. sensitivum showed an inhibitory effect on inducible nitric oxide synthase as well as bcl-2 expression, and up-regulated p53 and caspase-3 messenger RNA expression in B16F-10 melanoma cells. The regulation of proinflammatory cytokine production by tumor cells, tumor-associated macrophages, and resident macrophages accompanied by altered inducible nitric oxide synthase, bcl-2, caspase-3, and p53 messenger RNA expression by $B$. sensitivum methanol extract induces apoptosis in B16F-10 melanoma cells. ${ }^{40-43}$

\section{Betula utilis}

Betulinic acid (3 $\beta$-Hydroxy-lup-20(29)-en-28-oic acid), pentacyclic lupane-type triterpene is obtained from the chloroform bark extract of Betula utilis (Betulaceae). It exhibits selective cytotoxicity against several melanoma-derived cell lines by means of inducing apoptosis in cells irrespective of their p53 status. Because of its selective cytotoxicity against tumor cells and favorable therapeutic index, even at doses up to $500 \mathrm{mg} / \mathrm{kg}$ body weight, betulinic acid is a very promising new chemotherapeutic agent for the treatment of cancer. ${ }^{44}$

\section{Cuscuta reflexa}

The antitumor activity of the chloroform and ethanol extracts of whole plant of Cuscuta reflexa (Convolvulaceae) was evaluated against Ehrlich ascites carcinoma (EAC) tumor in mice at doses of 200 and $400 \mathrm{mg} / \mathrm{kg}$ body weight orally, respectively. Anticancer activity of the water extract of $C$. reflexa was analysed on Hep3B cells. The extract regulated down the lipopolysaccharide (LPS) induced over expression of TNF- $\alpha$ and COX-2 in RAW264.7 cells; blocked NF- $\kappa B$ binding to its motifs and induced apoptosis in Hep3B cells. The extract up regulated pro-apoptotic factors BAX and $\mathrm{p} 53$, and down regulated anti-apoptotic factors Bcl-2 and surviving. ${ }^{45,46}$

\section{Caesalpinia bonducella}

The methanol extract of Caesalpinia bonducella (Caesalpiniaceae) leaves (MECB) were evaluated for antitumor activity against Ehrlich ascites carcinoma (EAC)-bearing Swiss albino mice. The extract was administered at the doses of 50,100, and $200 \mathrm{mg} / \mathrm{kg}$ body weight per day for 14 days after $24 \mathrm{~h}$ of tumor inoculation. After the last dose and $18 \mathrm{~h}$ fasting, the mice were sacrificed. Parameters evaluated were growth of transplantable murine tumor, life span of EAC-bearing hosts, hematological profile, and biochemical parameters such as lipid peroxidation (LPO), glutathione content (GSH), superoxide dismutase (SOD), and catalase $(\mathrm{CAT})$ activities. MECB caused significant $(\mathrm{P}<0.01)$ decrease in tumor volume, packed cell volume, and viable cell count; and it prolonged the life span of EAC-tumor bearing mice. Hematological profile converted to more or less normal levels in extract-treated mice. MECB significantly $(\mathrm{P}<0.05)$ decreased the levels of lipid peroxidation and significantly $(\mathrm{P}<0.05)$ increased the levels of GSH, SOD, and CAT. The MECB was found to be devoid of conspicuous short-term toxicity in the mice when administered daily (i.p.) for 14 days at the doses of 50, 100, 200 , and $300 \mathrm{mg} / \mathrm{kg}$. The results indicate that MECB exhibited significant antitumor and antioxidant activity in EAC-bearing mice. ${ }^{47}$

\section{Cassia fistula}

Effects of methanolic extract (ME) of Cassia fistula (Fabaceae) seed on the growth of Ehrlich ascites carcinoma (EAC) and on the life span of tumor bearing mice were studied. ME treatment showed an increase of life span, and a decrease in the tumor volume and viable tumor cell count in the EAC tumor hosts. ${ }^{48}$

\section{Cassia tora}

Methanolic leaf extract of Cassia tora (Fabaceae) (CTME) was evaluated for antiproliferative activity of with Cisplatin using human cervical cancer cells (HeLa). The plant extract induced a marked concentration dependent inhibition on proliferation, reduced DNA content and apoptosis in HeLa. Phenolic compounds are responsible for the antiproliferative activity. ${ }^{49}$

\section{Cleome gynandra}

The anticancer activity of the methanol extract of whole plant of Cleome gynandra (Capparidaceae) (MECG) was evaluated in Swiss albino mice against Ehrlich Ascites Carcinoma (EAC) cell line at the doses of 200 and $400 \mathrm{mg} / \mathrm{kg}$ body weight intraperitoneally. MECG shows significant decrease in $(\mathrm{p}<0.01)$ tumour volume, viable cell count, tumour weight and elevated the life span of EAC tumor bearing mice. ${ }^{50}$

\section{Centella asiatica}

The crude extract (CE) of Centella asiatica (Apiaceae) inhibited the proliferation of the transformed cell lines significantly. $50 \%$ effective doses was found on 17 and $22 \mu \mathrm{g} / \mathrm{ml}$ for ehrlich ascites tumour cells (EAC) and dalton's lymphoma ascites tumour cells (DLA), respectively. Oral administration CE retarded the development of solid and ascites tumours and increased the life span of these tumour bearing mice. Asiatic acid (AA) is a pentacyclic triterpene found in Centella asiatica decreased viability and induced apoptosis in human melanoma SK-MEL-2 cells in a timeand dose-dependent manner. Furthermore, Ac-DEVD-CHO, a specific caspase-3 inhibitor, and Trolox prevented the AA-induced apoptosis. AA-induced apoptosis may be mediated through generation of ROS, alteration of Bax/Bcl-2 ratio and activation of caspase-3, but p53-independent. Asiatic acid was likely to confine the breast cancer cells in the S-G2/M phase mainly through the p38 pathway, because both SB203580 and p38 small interfering RNA (siRNA) inhibition significantly attenuated the accumulation of inactive phospho-Cdc2 and phospho-Cdc25C proteins and the cell numbers of S-G2/M phase. It is also known to be cytotoxic to U-87 MG human glioblastoma. This cell death occurs via both apoptosis and necrosis. The effect of AA may be cell type-specific as AA-induced cell death was mainly apoptotic in colon cancer RKO cells. AA-induced glioblastoma cell death is associated with decreased mitochondrial membrane potential, activation of caspase-9 and -3 , and increased intracellular free $\mathrm{Ca}^{2+}$. The aqueous extract (AE) of Centella asiatica leaves had a promising activity against mouse melanoma (B16F1), human breast cancer (MDA MB-231) and rat glioma (C6) cell lines, with $\mathrm{IC}_{50}$ values of $698.0,648.0$ and $1000.0 \mu \mathrm{g} / \mathrm{mL}$, respectively. The ability of methanolic extract of $C$. asiatica to induce apoptosis in different cancer cell lines, MCF-7 cells emerged as the most sensitive cell line for in vitro growth inhibitory activity was investigated. Triterpenes, phenolic and flavanoids constituents are responsible for the antiproliferative activity. ${ }^{51-55}$ 


\section{Cola nitida}

The potential anticarcinogenic effect of cola nut methanol extract on human breast cancer cell lines, MCF-7 was investigated. MCF7 cells treated with $80 \mu \mathrm{g} / \mathrm{ml}$ cola nut extract showed an increase of $8.29 \%$ in population of apoptotic cells with a concomitant decrease in the percentage of cells in the $\mathrm{S}$ and G2/M phase of cell cycle compared to DMSO-treated control cells. ${ }^{56}$

\section{Cirsium japonicum}

Potential antioxidant activities of methanol and water extracts of Cirsium japonicum (Asteraceae) (CJ) leaves and roots showed a concentration-dependent reducing power, ranging from 0.228 to 1.072 $(0.1 \sim 0.5 \mathrm{mg} / \mathrm{mL})$, as well as a high DPPH free radical-scavenging activity $\left(\mathrm{EC}_{50}=40.25 \mu \mathrm{g} / \mathrm{mL}\right)$. Anticancer activity of $C$. japonicum in the $\mathrm{S} 180$ and $\mathrm{H} 22$ mice was separated and purified with several chromatography techniques and two flavone compounds, pectolinarin and 5,7-dihydroxy-6,4'-dimethoxyflavone, were isolated and greatly inhibited cancer cell growth. The rate of inhibiting S180 mice was $55.77 \%$ at $50 \mathrm{mg} / \mathrm{kg}$, and the rate of life lengthening was $99.13 \%$ at $50 \mathrm{mg} / \mathrm{kg}$ in $\mathrm{H} 22$ mice. They inhibit the growth of the implanted tumors S180 and H22. The total phenolic (as tannic acid) and flavonoid (as quercetin) contents of the extract were $62.41 \mathrm{mg} / \mathrm{g}$ and $13.48 \mathrm{mg} / \mathrm{g}$, respectively. The cytotoxic activity indicated that the methanol extract has an inhibition activity in the stomach carcinoma cell (35.40\%). The content of the above two compounds in the methanol, ethanol, and aqueous extractions respectively was determined by HPLC as follows: pectolinarin $1.87 \%$, $1.65 \%, 1.27 \%$; 5,7-dihydroxy-6,4'-dimethoxyflavone: $0.515 \%, 0.42 \%$, $0.221 \%$. Furthermore, the anticancer activity of the two flavones in S180 and $\mathrm{H} 22$ mice was studied and these two flavones greatly inhibited cancer cell growth, and increased the life span. ${ }^{57-59}$

\section{Cephalotaxus harringtonia}

Several phytochemicals obtained from the chloroform extract of leaves and stems of Cephalotaxus harringtonia (Cephalotaxaceae) are cephalotaxine and its antitumor esters (harringtonine, isoharringtonine and homoharringtonine) in both callus and medium. It shows significant activity against experimental P388 leukemia and L-121O leukemia in mice. A new alkaloid deoxyharringtonine along with harringtonine, cephalotaxine (5\%), homoharringtonine $(80 \%)$, and isoharringtonine, with significant antileukemic activity has been isolated from $C$. harringtonia. Homoharringtonine (HHT), a protein synthesis inhibitor decreases the level of KIT protein by inhibiting translation, resulting in a decreased level of phospho-KIT and abrogating its constitutive downstream signaling. Imatinib-sensitive HMC-1.1 cells harboring the mutation V560G in the juxtamembrane domain of KIT, imatinib-resistant HMC-1.2 cells harboring both V560G and D816V mutations, and murine P815 cells were treated with HHT and analyzed in terms of growth, apoptosis, and signal transduction. ${ }^{60-62}$

\section{Crocus sativus}

Crocin, crocetin, picrocrocin and safranal are isolated from $80 \%$ ethanol extracts of the whole plant of Crocus sativus (Iridaceae) have been reported to inhibit cell growth of human tumor cells, P38B, S-180, EAC and DLA tumour cells in vitro. Saffron can prevent chemically induced skin carcinogenesis in Swiss Albino Mice. Crocin Inhibits proliferation, nucleic acid synthesis and induces apoptosis in the human tongue squamous cell Carcinoma Cell Line, Tca 8113 . The proliferation was reduced most significantly in HCT-116 cells, to $45.5 \%$ at $1.0 \mathrm{mg} / \mathrm{ml}$ and to $6.8 \%$ at $3.0 \mathrm{mg} / \mathrm{ml}$. Three doses of saffron $(20,40$ and $80 \mathrm{mg} / \mathrm{kg} \mathrm{b.w.)}$ were orally administered to mice for five consecutive days prior to the administration of anti-tumor drugs under investigation. Tca8113 cells were treated with crocin for $24,48,72$, and $96 \mathrm{~h}$ at concentrations of
$0.1,0.2,0.4$, and $0.8 \mathrm{mM}$. Saffron corms have been demonstrated to contain a proteoglycan that inhibits growth of human tumor cells. Callus cultures of saffron corm also synthesize such glycoconjugate. This compound is cytotoxic against human cervical epithelioid carcinoma cells $\left(\mathrm{IC}_{50}=7 \mathrm{mg} / \mathrm{ml}\right.$ ), and consists of approximately $90 \%$ carbohydrate and $10 \%$ protein. ${ }^{63-65}$

\section{Cinnamomum zeylanicum}

The anti-neoplastic activity of the aqueous extract of cinnamon bark $(\mathrm{ACE}-\mathrm{C})$ in cervical cancer cell line was reported through increase in intracellular calcium signaling as well as loss of mitochondrial membrane potential, $\mathrm{SiHa}$ due to downregulation of MMP-2 expression. In addition, $C$. zeylanicum (Lauraceae) aqueous extract significantly $(\mathrm{P}<0.01)$ induced 20 and $37 \%$ thymic cells lymphoproliferation at 62.5 and $125 \mu \mathrm{g} / \mathrm{ml}$ respectively. Petroleum ether and chloroform extracts of C. zeylanicum bark for possible cytotoxic effect on KB and L1210 cell cultures was investigated an the median effective doses of the petroleum ether extract on KB and L1210 cells were 60 and $24 \mu \mathrm{g} / \mathrm{ml}$, respectively, and of the chloroform extract were 58 and $20 \mu \mathrm{g} / \mathrm{ml}$, respectively. Cytotoxic effect of cinnamaldehyde from an aqueous cinnamon extract (ACE) from the bark of $C$. zeylanicum to cancerous cells revealed that cinnamaldehyde was able to induce apoptosis with changes in nuclear morphology, DNA fragmentation, and cell morphology, a rapid loss of mitochondrial transmembrane potential, stimulation of reactive oxygen species (ROS) production, release of mitochondrial cytochrome $c$ into cytosol, and subsequent induction of procaspase- 9 and procaspase- 3 processing. Trans-cinnamic aldehyde (cinnamaldeyde, CA), and an ethanolic extract $(\mathrm{CE})$ prepared from $C$. cassia bark, displays equipotent activity as inducers of Nrf2 transcriptional activity in human colon cancer cells (HCT116, HT29) and non-immortalized primary fetal colon cells (FHC). ${ }^{66-69}$

\section{Conyza canadensis}

Methanol extract of the roots of Conyza canadensis (Asteraceae) led to the isolation of two new dihydropyranones named conyzapyranone $\mathrm{A}$ and $\mathrm{B}$, and the known $4 Z, 8 Z$-matricaria- $\gamma$-lactone, $4 E, 8 Z$-matricaria$\gamma$-lactone, 9,12,13-trihydroxy-10(E)-octadecenoic acid, epifriedelanol, friedeline, taraxerol, simiarenol, spinasterol, stigmasterol, $\beta$-sitosterol, and apigenin. The isolated compounds were evaluated for their antiproliferative activities and were demonstrated to exert considerable cell growth-inhibitory activity against human cervix adenocarcinoma (HeLa), skin carcinoma (A431), and breast adenocarcinoma (MCF-7) cells. The antitumor activities of novel antitumor, duocarmycins (DUMs), A, B1, B2, C1 and C2, obtained from the extract of Conyza Canadensis were examined against human and murine tumor cells, also inhibited the growth of adriamycin (ADM)-resistant lines of human nasopharynx carcinoma KB cells and breast carcinoma MCF-7 cells as well as their sensitive lines. ${ }^{70}$

\section{Clausena lansium}

Ethyl acetate fraction (EAF) of Clausena lansium (Rutaceae) has strong anticancer activities against human gastric carcinoma (SGC7901), human hepatocellular liver carcinoma (HepG-2) and human lung adenocarcinoma (A-549) cancer cell lines, higher than cisplatin, a conventional anticancer drug. An investigation of $C$. lansium seed extract led to the isolation and identification of two new amides, clausenalansamide $\mathrm{A}$ and clausenalansamide $\mathrm{B}$ along with three known amides, were evaluated for their anti-cancer activity against three human cancer cell lines, KB, MCF7 and NCIH187. The phenolic and flavanoids content of the extract is responsible for antiproliferative activity. ${ }^{71,72}$ 


\section{Croton macrobotrys}

n-hexane, dichloromethane and methanol extracts of the whole plant of Croton macrobotrys (Euphorbiaceae) were evaluated for their in vitro antiproliferative activity on cell lines, 786-0 (kidney), HT-29 (colon), K562 (leukemia), NCI-ADR/RES (drug resistant ovary), NCI-H460 (lung), MCF-7 (mammary), PC-3 (prostate), OVCAR-3 (ovary), U251 (glioma) and UACC-62 (melanoma). The dicloromethane extract exhibited activity against all cell lines at the concentration $25 \mu \mathrm{g} / \mathrm{mL}$, and on particular cell lines NCI-H460 (GI50 $0.33 \mu \mathrm{g} / \mathrm{mL}$ ) and K5662 (GI50 $0.91 \mu \mathrm{g} / \mathrm{mL}$ ). Extract contains several phytoconstituents like (corydine, an alkaloid), steroid, $\beta$-sitosterol and the triterpenoid, $\beta$-amyrin. Corydine and salutaridine (both alkaloids) are important compounds in the dichloromethane extract, while stigmasterol and $\beta$-sitosterol are minor constituents. $^{73}$

\section{Dracocephalum tanguticum}

A chloroform extract of the whole plant of Dracocephalum tanguticum (CEDT) (Lamiaceae) was found to contain high content of sapogenin or saponin (53.7\%). $90 \mu \mathrm{g} / \mathrm{ml}$ dose of CEDT was effective in anticancer activity on T98G glioblastomas cells by induction of cell apoptosis via Caspase- 3 and Bax pathways, along with an inhibition of p21. The cells treated by $30 \mu \mathrm{g} / \mathrm{ml}$ of CEDT for $72 \mathrm{~h}$ and treated by $90 \mu \mathrm{g} / \mathrm{ml}$ of CEDT for $48 \mathrm{~h}$ showed the characteristic features of apoptosis as cell volume shrinkage, cell blebbing, cell detachment and apoptotic bodies compared with the adherent and spindle-shaped control cells. Saponin-rich extract displayed significant antiproliferation properties in T98G glioblastomas cells. $^{74}$

\section{Dioscorea collettii}

Methyl protodioscin (MPD) extracted from Dioscorea colletti (Dioscoreaceae) has anti-proliferative effect on the HepG2 cells and cytotoxicity against most cell lines from solid tumors. It results in G2/M arrest and apoptosis in HepG2 cells. These effects were attributed to down-regulation of Cyclin B1 and the signaling pathways leading to up-regulation of Bax and down-regulation of BCL2, suggesting that methyl protodioscin may be a novel anti-mitotic agent. MPD, ranging from 2.5 to $20 \mathrm{mM}$, significantly inhibited growth of HepG2 cells in a time- and dose-dependence manner. The antiproliferative effect of dioscin on human gastric carcinoma SGC-7901 cells is by upregulation of Fas, FasL (Fas ligand), TNF- $\alpha$, TNF receptor-1, TNF receptor-associated factor 1 and Fas-associated protein with death domain demonstrated involvement of the death receptor pathway. Increased mRNA expression of $\mathrm{p} 53$ was also found in dioscin-treated SGC-7901 cells, and the activation of caspase- 3 and -8 was also observed. Cells were treated with different concentrations of dioscin $\left(0.65,1.3\right.$ and $\left.2.6 \mu \mathrm{g} / \mathrm{ml}^{-1}\right)$ and HCPT $\left(10.4,20.8\right.$ and $\left.41.6 \mu \mathrm{g} / \mathrm{ml}^{-1}\right)$ under different treatment times $(12,24,48$, and $72 / \mathrm{h})$. This concentrations show that the growth of cancer cells was significantly inhibited by dioscin and HCPT. ${ }^{75,76}$

\section{Emilia sonchifolia}

The anticancer efficacy of n-hexane extract of whole plant of Emilia sonchifolia (Asteraceae) was determined in mice using Dalton's lymphoma ascitic (DLA) cells. The hexane extract was found to be most active in a concentration and time-dependent manner; it induced membrane blebbing, nuclear condensation, DNA ladder formation, and formation of apoptotic bodies which are characteristic to apoptotic cell death. This isolate induced apoptotic cell death in DLA cells at $0.8 \mu \mathrm{g} / \mathrm{mL}$ level. The isolated flavonoid fraction from the whole plant of Emilia sonchifolia (ES) has possible antitumor activity, compared with quercetin. The inhibitory concentration $50 \%\left(\mathrm{IC}_{50}\right)$ values obtained for superoxide production was $48 \mu \mathrm{g}$ (Flavonoid fraction of ES) compared to $32 \mu \mathrm{g}$ for quercetin. Methanolic extract of Emilia sonchifolia was found to be cytotoxic to Daltons lymphoma (DL), Ehrlich ascites carcinoma (EAC) and mouse lung fibroblast (L-929) cells, but not toxic to normal human lymphocytes, under in vitro conditions. Oral administration of the extract $(100 \mathrm{mg} / \mathrm{kg}$, b. wt) to mice reduced the development of both solid and ascites tumors and increased the life span of these tumor bearing mice. ${ }^{77}$

\section{Euphorbia hirta}

The antiproliferative activity of the methanol extract of leaves of Euphorbia hirta (Euphorbiaceae) on HepG2 cells from human epithelioma of larynx was investigated. The dose, $625 \mu \mathrm{g} / \mathrm{ml}$ of methanol extract showed the antiproliferative activity. The acetone root extracts of $E$. hylonoma were investigated for 1,1-diphenyl-2-pycrylhydrazyl (DPPH) free radical, superoxide anion and hydroxyl radical scavenging activity and cytotoxic activity against the human hepatoma cell line SMMC-7721, human cervix epitheloid carcinoma cell line HeLa and the human gastric cancer cell line SGC-7901. The acetone extract and fraction of EtOAc showed high antioxidant activities. The acetone extract and fraction of water showed a stronger cytotoxic effect on all tested cells, with $\mathrm{IC}_{50}$ values being less than $20 \mu \mathrm{g} / \mathrm{mL}$. The acetone extract and fraction of water induced cell cycle arrest in G1 phase in SMMC-7721 cells. The major compounds isolated from the acetone extract were ellagic acid derivatives, 3',4-tri-O-methylellagic acid, 3,3'-di-O-methylellagic acid, 3-O-methylellagic acid and 3,3'-di-O-methylellagic acid-4'-O$\beta$-dxylopyranosid. ${ }^{78,79}$

\section{Emblica officinalis}

The efficacy of methanolic extract of Emblica officinalis (Phyllanthaceae) fruits polyphenol fraction (EOP) on the induction of apoptosis in mouse and human carcinoma cell lines (Dalton's Lymphoma Ascites (DLA) and CeHa cell) at $200 \mu \mathrm{g} / \mathrm{ml}$ dose and its modulatory effect on N-nitrosodiethylamine (NDEA) induced liver tumors at $60 \mathrm{mg} / \mathrm{kg}$ in rats were determined. Aqueous extract of $E$. officinalis was found to be cytotoxic to L929 cells, ascites and solid tumours in mice induced by DLA cells in a dose dependent manner. Concentration needed for $50 \%$ inhibition was found to be $16.5 \mu \mathrm{g} / \mathrm{ml}$. The effects of extracts from Emblica officinalis were able to induce programmed cell death of mature osteoclastogenesis (OCs), without altering, at the concentrations, the process of osteoclastogenesis. E. officinalis increased the expression levels of Fas, a critical member of the apoptotic pathway. The Emblica officinalis extracts selectively compete with the binding of transcription factor NF-kB to its specific target DNA sequences. The $0.5,5$ and $50 \mu \mathrm{g} / \mathrm{ml}$ of $E$. officinalis extracts did not cause any cytotoxic effect on the total cell population, but extracts at $500 \mu \mathrm{g} / \mathrm{ml}$ were found to induce a slight but not significant decrease of viability. Pyrogallol, a catechin compound, is an active component of Emblica officinalis extracts and has an anti-proliferative effect on some human cancer cell lines. Pyrogallol had highly cytotoxic effect on human lung cancer cell lines and less effect on human bronchial epithelium cell line. Polyphenolic fraction of E. officinalis is responsible for the mechanism of induction of apoptosis..$^{80-82}$

\section{Gmelina asiatica}

The effect of lignans and flavonoids obtained from the ethyl acetate extract of Gmelina asiatica (Lamiaceae) roots (EGAR) on estrogen receptor-positive (MCF-7) and negative (MDA-MB-231) human breast cancer cell lines were studied. Down-regulation of the proliferative activity occurred in a clear dose-dependent response with $\mathrm{IC}_{50}$ values of $32.9 \pm 3.8 \mu \mathrm{g} / \mathrm{mL}$ in MCF-7 and $19.9 \pm 2.3 \mu \mathrm{g} / \mathrm{mL}$ in MDA-MB-231 cell lines. Plant extracts of $G$. asiatica were observed to induce apoptosis of MCF-7 cells, cell-morphological changes and chromatin condensation. The cytotoxicity of the chloroform extract was greater than other extracts of $G$. asiatica. ${ }^{83}$ 


\section{Heracleum persicum}

Antitiumor activity was found in the methanol and petroleum ether extract from the root and fruits of Heracleum persicum (Apiaceae) and had inhibition effects on Agrobacterium tumefaciens which induced crown gall tumor on potato disk. Essential oils from $H$. persicum also exhibited antitumor activity where $\mathrm{IC}_{50}$ value was $2.24 \mathrm{mg} / \mathrm{mL} .^{84}$

\section{Hibiscus mutabilis}

A hexameric $150-\mathrm{kDa}$ lectin was isolated from dried Hibiscus mutabilis (Malvaceae) seeds using a chromatographic protocol that involved ion exchange chromatography on SP-Sepharose, and gel filtration on Superdex 75 and Superdex 200. The hemagglutinating activity of the lectin, which was stable at pH 4-7 and up to 50 degrees C, could be inhibited by $25 \mathrm{mM}$ galactonic acid. This is the first report of a galactonic acid-binding lectin. It potently inhibited HIV-1 reverse transcriptase with an $\mathrm{IC}_{50}$ of 0.2 microM. It exhibited weak antiproliferative activity towards both hepatoma HepG2 cells (40\% inhibition) and breast cancer MCF-7 cells (50\% inhibition) at 100 microM concentration of the lectin. It did not inhibit mycelial growth of a number of fungi tested. ${ }^{85}$

\section{Hedyotis diffusa}

The cellular effects of the ethanol extract of whole plant of Hedyotis Diffusa (EEHDW) (Rubiaceae) in the HT-29 human colon carcinoma cell line inhibited the growth of HT-29 cells, demonstrating EEHDWinduced cell morphological changes, collapse of mitochondrial membrane potential, activation of caspase- 9 and caspase-3, and increase of the ratio of pro-apoptotic Bax to anti-apoptotic Bcl-2, suggesting that the HT-29 cell growth inhibitory activity of EEHDW. The isolated splenocytes from $H$. diffusa extract-treated leukemic mice demonstrated an increase of T- and B-cell proliferation in vivo. HDW extract would appear to have antileukemia activity in WEHI-3 cell-induced leukemia in vivo. H. diffusa had a significant inhibition of cell growth and induction of cell apoptosis in COLO 205 (colon cancer), Hep 3B (hepatocellular carcinoma) and $\mathrm{H} 460$ (lung cancer) cell lines. Ursolic acid has significant anti-tumor activity in COLO 205, Hep 3B and H460 cancer cells. Two marker compounds were identified exclusively in $\mathrm{H}$. diffusa: 6-O-(E)-pcoumaroyl scandoside methyl ester (1) and 10(S)-hydroxypheophytin a (2). Both compounds showed moderate anti-proliferation effect on PC3 human androgen-independent prostate cancer cells, while compound 2 also showed strong anti-proliferation effect on LNCaP human androgen-sensitive prostate cancer cells. The mechanisms of methylanthraquinone from Hedyotis diffusa induced MCF-7 cells apoptosis via $\mathrm{Ca}^{2+} /$ calpain /caspase-4 pathway. Methylanthraquinone strongly induced cleavage of caspase-4, caspase- 9 and caspase-7 in MCF-7 cells. Lipophilic extract and crude polysaccharide were prepared from Hedyotis diffusa, with water extraction, alcohol extraction and defatting/water extraction and alcohol precipitation, respectively. The water-soluble crude polysaccharides separated from $H$. diffusa and the lipophilic extract of $H$. diffusa showed the anti-tumor activities. Combined administration of the lipophilic extract and the crude polysaccharides did not show the synergistic anti-tumor activity. Apoptosis of THP-1 cells were found when treated with 2-hydroxy-3-methylanthraquinone from $H$. diffusa. Apoptosis was associated with a more prominent induction expression of Fas/FasL, DR4 and TRAIL in a time-dependent manner. Apoptosis of THP-1 cells were found when treated with 2-hydroxy3-methylanthraquinone from $H$. diffusa. Apoptosis was associated with a more prominent induction expression of Fas/FasL, DR4 and TRAIL in a time-dependent. ${ }^{86-88}$

\section{Indigofera linnaei}

Methanol extract of Indigofera linnaei (MEIL) of family Fabaceae was investigated for antitumor activity against transplantable tumors and human cancer cell lines HeLa, Hep-2, HepG-2, MCF-7, HT-29, Vero and NIH 3T3 cells. At the dose of 200 and $400 \mathrm{mg} / \mathrm{kg}$, significantly increase the mean survival time, exerted a protective effect on the hemopoietic system and significantly reduce solid tumor volume. The extract of 1. linnaei is rich in flavonoids and saponins. Flavonoids have been found to possess antimutagenic and antimalignant effect. Moreover, they have a chemo preventive role in cancer through their effects on signal transduction in cell proliferation and inhibition of neovascularization. Saponins have been found beneficial targeted on inhibition of tumor angiogenesis by suppressing its inducer in the epithelial cells of blood vessels and then on adhering, invasion and metastasis of tumor cells. They also exhibit the antitumor effect by cell cycle arrest and apoptosis. ${ }^{89}$

\section{Leea indica}

The crude methanolic extract of the leaves of Leea indica (Vitaceae) was examined for their anti tumor activity against Ehrlich Ascites Carcinoma (EAC) cells in Swiss albino mice. The compound at the dose of $40 \mathrm{mg} / \mathrm{kg} /$ day significantly decreases tumor weight. Glycosides, mollic acid arabinoside (MAA) and mollic acid xyloside (MAX), were firstly isolated from the fresh leaves of $L$. indica, inhibited the growth of $\mathrm{Ca}^{2+}$ Ski cervical cancer cells with $\mathrm{IC}_{50}$ of $19.21 \mu \mathrm{M}$. Remarkable cytotoxic activity shown by $L$. indica extracts can be attributed mainly to phenol, flavonoids and gallic acid. Gallic acid is isolated from the leaves of $L$. indica and active against several cancer cell lines. Cytotoxic compounds trigger apoptosis through two signaling mechanisms- the activation and release of mitochondrial pro-apoptotic proteins known as caspases under the control of Bcl-2 family of proteins or up regulated expression of proapoptotic receptors on cancer cells, whose subsequent interaction with their ligands activates apoptotic signaling pathways. These receptors include the Fas (also called APO-1 or CD95) and the tumor necrosis factor (TNF)-related apoptosis inducing ligands (TRAIL) receptors. ${ }^{90-91}$

\section{Liriodendron tulipifera}

The methanolic extract of the stem, leaves and roots bark of Liriodendron tulipifera (Magnoliaceae) showed significant activity against the KB cell culture and inhibitory activity towards farnesyl protein transferase (FPTase). 977). Three active constituents, costunolide, tulipinolide, liriodenine and a new germacranolide, were isolated which are having antiproliferative activity. Two sesquiterpenes, Lipiferolide and Isorhamnetin inhibited the FPTase activity at the dose of $83 \mu \mathrm{g} / \mathrm{ml}$ and $12 \mu \mathrm{g} / \mathrm{ml}$ respectively. This extract also exhibits the anti-proliferative activity and induction of the G2/M arrest in human colon tumor HT-29 cells..$^{92,93}$

\section{Litchi Chinensis}

The ethyl acetate extract of Litchi Chinensis (Sapindaceae) fruit pericarp (LFP) displays inhibitory effect on human breast cancer. The major flavanols in the LFP are reported to be procyanidin B4, procyanidin B2 and epicatechin, while cyanindin-3-rutinside, cyanidin-3-glucoside, quercetin-3-rutinosde and quercetin-3-glucoside are identified as the important anthocyanins. Epicatechin and the ethyl acetate fraction showed a significantly $(\mathrm{P}<0.05)$ stimulatory effect when the concentration was up to $12.5 \mu \mathrm{g} / \mathrm{ml}$. Procyanidin B4 and the ethyl acetate fraction show a stronger inhibitory effect on HELF than MCF-7 proliferation, while epicatechin and procyanidin B2 have lower cytotoxicities towards MCF-7 and HELF than paclitaxel. Human breast cancer cells were tested in vitro for cytotoxicity and, colony formation inhibition. LFP extract demonstrated a dose- and time-dependent inhibitory effect on cell growth $\left(\mathrm{IC}_{50}=80 \mu \mathrm{g} / \mathrm{ml}\right)$, and it significantly inhibited colony formation and BrdU incorporation of human breast cancer cells. The findings in this study suggested that LFP extract might have potential anticancer activity on both ER positive and negative breast cancers. Litchi chinensis leaf extract (LCLE) at concentrations of 50, 100, $150 \mu \mathrm{g} / \mathrm{ml}$ significantly 
inhibited the growth of three human leukemic cell lines-U937, K562 and HL-60. While U937 and K562 cell populations were arrested in the G2-M phase, the HL-60 cell population was arrested in the $G_{1}$ phase of cell cycle. LCLE induced apoptosis is mediated through mitochondrial intrinsic pathway involvement. Animal studies have demonstrated that a dietary polyphenol known as tannic acid (TA) exhibits anticarcinogenic activity in chemically induced cancers. Based on the potent antioxidant activity of LFP extract and its major components of polyphenolic compounds and flavonoids, it could be assumed that LFP extract might have anticancer activity against some cancer cells and/or animal models. ${ }^{94,95}$

\section{Moringa oliefera}

The chemopreventive efficacy of the hydroalciholic extract of Moringa oliefera (Moringaceae) was evaluated in a two stage model of 7,12dimethyl benz(a)-anthracene induced skin papillomagenesis. Topical application of the extract at a dose of $5 \mathrm{mg} / \mathrm{kg}$ body weight inhibited the tumor multiplicity. The ethanol extract of the seeds of $M$. oleifera were examined and the new O-ethyl-4-( $\alpha$-l-rhamnosyloxy)benzyl carbamate together with seven known compounds, 4( $\alpha$-l-rhamnosyloxy)benzyl isothiocyanate, niazimicin, niazirin, $\beta$-sitosterol, glycerol-1(9-octadecanoate), 3-O-(6'-O-oleoyl- $\beta$-d-glucopyranosyl)- $\beta$-sitosterol, and $\beta$-sitosterol-3-O- $\beta$-d-glucopyranoside were isolated. At a dosage of $100(\mathrm{ug} / \mathrm{ml})$ the extract inhibited EBV-EA formation by 100 percent suggesting its antitumor-promoting activity. Niazimicin was further subjected to in vivo test and found to have potent antitumor promoting activity in the two-stage carcinogenesis in mouse skin using 7,12-dimethylbenz(a)anthracene (DMBA) as initiator and TPA as tumor promoter. Niazinin $A$, niazimicin, and niaziminin $A+B$ resulted from bioassay-directed fractionation of the ethanolic extract of $M$. oleifera leaves. The different extracts from the leaves and roots of $M$. oleifera for activity against in lymphoblastic leukemia (ALL) and acute myeloid leukemia (AML) as well as a culture of hepatocarcinoma cells and in ovarian cancer was found. The antiproliferative effect of MLE was also associated with induction of apoptosis as well as morphological changes and DNA fragmentation. The crude extracts of the callus of $M$. oleifera were evaluated in vitro for their activity against leukemia cells and hepatocarcinoma. Among the different concentrations, at $0.1 \mathrm{mg} / \mathrm{l}$ has effective activity against cancer. Ethanolic extracts killed about $36 \%$ of abnormal cells among primary cells harvested from 3 patients with acute myeloid leukemia (AML) and hepatocarcinoma cells HpG2.96-98

\section{Magnolia sieboldii}

An aqueous extract of $M$. officinalis (Magnoliaceae) inhibited cell viability and DNA synthesis in cultured human urinary bladder cancer 5637 cells. Inhibition of proliferation was the result of apoptotic induction, because FACS analyses of 5637 cells treated with $M$. officinalis showed a sub-G1 phase accumulation. The extract also increased cytoplasmic DNA-histone complex dose-dependently. These inhibitory effects were associated with the upregulation of proapoptotic molecules Bax, cytochrome $\mathrm{c}$ and caspase 3 . Treatment of 5637 cells with $M$. officinalis extract suppressed the expression of matrix metalloproteinase 2 (MMP-2) and MMP-9, as revealed by zymographic and immunoblot analyses. When the extract was given to mice simultaneously with the carcinogen N-butyl-N-(4-hydroxybutyl) nitrosamine, which induces urinary bladder tumors, the size of the induced tumors was smaller. Histological data indicated that the histological grade of carcinoma and the depth of invasion were dramatically decreased by treatment with $M$. officinalis extract in mice with N-butyl-N-(4-hydroxybutyl) nitrosamine-induced urinary bladder tumors. ${ }^{99}$

\section{Matricaria chamomilla}

The anticancer properties of aqueous and methanolic extracts of chamomile (Matricaria chamomilla, Asteraceae) flower against various human cancer cell lines causes minimal growth inhibitory responses in normal cells, whereas a significant decrease in cell viability was observed in various human cancer cell lines. Chamomile extract confirmed apigenin 7-O-glucoside as the major constituent of chamomile. ${ }^{100}$

\section{Mallotus philippinensis}

95\% ethanolic, 50\% ethanolic and aqueous extract of glands/hairs obtained from the fruits of Mallotus philippinensis (Euphorbiaceae) at the concentration of $100 \mu \mathrm{g} / \mathrm{ml}$ were studied for in vitro cytotoxic activity against 14 human cancer cell lines from nine different origins. Results revealed that the $95 \%$ ethanolic extract showed highest in vitro cytotoxic effect against all the 14 human cancer cell lines. The fractions of $95 \%$ ethanolic extract were obtained and it was found that the significant cytotoxic potential was produced by the chloroform soluble fraction at $100 \mu \mathrm{g} / \mathrm{ml}$ as this fraction inhibited the growth of ten human cancer cell lines from seven different tissues. Chromatographic analysis of the said fraction afforded a polyphenolic molecule rottlerin, which at the concentration of $1 \times 10^{-5} \mathrm{M}$ and $1 \times 10^{-4} \mathrm{M}$ suppressed the proliferation of eight human cancer cell lines from six different tissues and proved its exceptionally remarkable in vitro anticancer efficiency. ${ }^{101}$

\section{Nelumbo nucifera}

(S)-armepavine (C19H23O3N; MW313) from ethanolic leaves extract of Nelumbo nucifera (Nelumbonaceae) inhibits the proliferation of human PBMCs activated with PHA. The main polyphenols identified in the above extract were gallic acid, rutin, and quercetin. Cell-cycle arrest of MCF-7 cells treated with NLE at the G0/G1 phase. Its flower also has antitumor activity. Significant growth inhibition effects of procyanidins from Nelumbo nucifera seed pod on mouse melanoma B16 were found both in vivo and in vitro through diverse mechanisms, including cell-cycle arrest, induction of tumour cell death by apoptosis. Neferine obtained from seeds of Nelumbo nucifera possessed a potent growth inhibitory effect on human osteosarcoma cells, by cell cycle arrest at G1. (S)-armepavine, an isoquinoline alkaloid, possesses cytotoxic activity on L929 fibroblast cells. ${ }^{102-103}$

\section{Operculina turpethum}

Antioxidant activity of methanolic extract of $O$. turpethum (Convolvulaceae) stems (100 mg/kg for 45 days) on 7,12 dimethylbenz(a) anthracene (DMBA) induced breast cancer was investigated in female Sprague-Dawley rats. A significant increase in lipid peroxidation levels were observed in tested samples of cancer induced rats while the activities of enzymatic antioxidants such as superoxide dysmutase, catalase, glutathione peroxidase and nonenzymatic antioxidants like glutathione, ascorbic acid and alpha tocopherol were decreased in cancer bearing animals when compared to controlled animals. Significant increase in breast tumor weight was observed in DMBA group while breast tumor weight decreased significantly in combination of DMBA and O. turpethum extract group. ${ }^{104}$

\section{Oldenlandia diffusa}

Leaf methanol and hexane extract of Oldenlandia diffusa (Rubiaceae) has been identified for antitumor properties through Agrobacterium tumefaciens infection. Significant tumor inhibition was observed at $100 \mathrm{ppm}$ and $1000 \mathrm{ppm}$ of the extract. Maximum tumor inhibition of $40.98,41.93$ and $41.89 \%$ were observed at $1000 \mathrm{ppm}$ for the accessions of the Agrobacterium tumefaciens AtTa0112, AtAc0114 and AtSl0105 respectively. The water extract of $O$. diffusa exhibited a strong antiproliferative activity against all cancer cell lines one murine (B16-F10), seven human cancer cell lines (A5-49, C-33A, MCF-7, Ln-Cap, Tsu-Pr1, MDAMB-453, DU-145) and one normal human pancreatic cell line. The concentrations of growth inhibition at $50 \%\left(\mathrm{IC}_{50}\right.$ ) ranged from 7 to $25 \mathrm{mg}$ raw material $/ \mathrm{ml}$ after 48 -hour treatment. The extract had a very limited 
cytotoxicity (10\% inhibition) on the normal pancreatic cells even at the concentration of $50 \mathrm{mg} / \mathrm{mL}$. Treatment of the cancer cells with the ethanol extract of $O$. diffusa component markedly increased the production of superoxide within few hours. Significant elevation in the protease activities of caspases- 2 and -3 were detected. The $\mathrm{LD}_{50}$ of the ethanol extract was estimated to be approximately $320 \mu / \mathrm{ml}$. O. diffusa (OD) extracts strongly inhibited cell growth and induced apoptosis in Estrogen Receptor alpha (ER $\alpha)$-positive breast cancer cells, whereas proliferation and apoptotic responses of MCF-10A normal breast epithelial cells were unaffected. Mechanistically, OD extracts enhance the tumor suppressor p53 expression as a result of an increased binding of ERa/Sp 1 complex to the p53 promoter region. Isolated ursolic and oleanolic acids as the bioactive compounds able to upregulate $\mathrm{p} 53$ expression and inhibit breast cancer cell growth. These acids were greatly effective in reducing tamoxifen-resistant growth of a derivative MCF-7 breast cancer cell line resistant to the antiestrogen treatment. The enhanced ability of oleanolic acid (OA) to cause cytotoxicity in transformed cells in the presence of normal fibroblasts is also observed with the human hepatocellular carcinoma cell line, SMMC-7721. Ursolic acid (UA), a triterpenoid compound isolated previously from $O$. diffusa, was found to inhibit the proliferation of doxorubicin-resistant human hepatoma cell line (R-HepG2) through apoptosis. The effect of $O$. diffusa significantly inhibited the growth of the HL60s and induced apoptosis in a cell cycle-independent fashion, possibly through the induction of genotoxic damage. $O$. diffusa has been used in treating liver, lung and rectal tumors. The effects of these phytochemicals on oxidative burst as an indicator of phagocytic function in a murine macrophage cell line J774. The effect of OD on the growth of a murine renal cell carcinoma (Renca) was also determined. Dose $4 \mathrm{mg} /$ day significantly inhibited the growth of Renca in mice. O. diffusa is commonly used for curing promising anticancer effects on the number of tumor cell lines. Stearic acid (SA) was isolated and identified from $O$. diffusa as one of the active components showed inhibitory effects on the growth human hepatoma cell lines, HepG2 and Hep3B cells with induction of sub-G1 population, dna fragmentation, changing of mitiochondrial transmembrane potential and expression of caspase precursors. Terpenoids, phenolics and alkaloids found in the extract showed antiproliferative activity but triterpenoids have highest antiproliferative activity than others. ${ }^{105-107}$

\section{Ophiorrhiza mungos}

The anticarcinogenic potential of the phytocompound Luteolin-7O-glucoside (LUT7G) and camptothecin, isolated from the methanolic extract of leaves and roots of Ophiorrhiza mungos (Rubiaceae) was studied against 4 different cancer cell lines (COLO 320 DM, AGS, MCF-7, and A549) and normal VERO cell line. The ability of LUT7G to induce apoptosis was determined by its antiradical activity, DNA fragmentation, expression of $\beta$-catenin, and chemopreventive efficacy in vivo. $20 \mathrm{mg} / \mathrm{kg}$ of the dose is effective in the inhibition of tumor activity of cells. ${ }^{108}$

\section{Ocimum sanctum}

An aqueous and ethanolic extract of Ocimum sanctum (lamiaceae) leaves has been investigated against human fibrosarcoma cells (HFS cells) and a significant reduction in tumor volume of mice bearing Sarcoma-180 solid tumors. Ethanol extracts of Ocimum sanctum (EEOS) has antitumor mechanism in A549 cells and the Lewis lung carcinoma (LLC) animal model. The chemopreventive efficacy of extract of $\mathrm{O}$. sanctum (OS) against $\mathrm{N}$-methyl $\mathrm{N}$-nitro-N-nitrosoguanidine (MNNG)-induced gastric carcinogenesis, based on changes in oxidantantioxidant status, cell proliferation, apoptosis and angiogenesis by reducing glutathione level. The anti neoplastic effect of the leaves of OS against Ehrlich Ascites Carcinoma (EAC) in mice at the doses of $50 \mathrm{mg} / \mathrm{kg}$ body weight intraperitoneally significantly $(\mathrm{p}<0.001)$ increased survival times. In the extract of this plant terpenoids, steroids and phenolic compounds have a chemopreventive role in cancer through their effects on signal transduction in cell proliferation. ${ }^{109-110}$

\section{Phaseolus vulgaris}

Twenty-one-day-old female Sprague Dawley rats were given an intraperitoneal injection of 1-methyl-1-nitrosourea and $7 \mathrm{~d}$ after carcinogen injection were randomized to 1 of 5 groups fed a modification of the AIN$93 \mathrm{G}$ diet formulation containing $0,7.5,15,30$, or $60 \%$ (wt:wt) small red dry bean (Phaseolus vulgaris, L.) (Fabaceae) incorporated as cooked, freeze-dried, and milled powder. All experimental diets had the same macronutrient content based on proximate analysis. Compared with the control group, dry bean consumption resulted in dose-dependent reductions in mammary cancer incidence, cancer multiplicity, and tumor burden. Dry bean consumption was associated with dose-dependent reductions in plasma concentrations of glucose, insulin, insulin-like growth factor-1, C-reactive protein, and interleukin- 6 in food-deprived rats. Analysis of mammary adenocarcinomas indicated that a dominant mechanism accounting for reduced tumor burden was the induction of apoptosis. B cell lymphoma 2 and X-linked inhibitor of apoptosis protein levels decreased and BCL-2-associated X protein increased with increasing dry bean consumption, findings consistent with the induction of apoptosis via the mitochondrial pathway. These data demonstrate that a legume without noteworthy content of isoflavones inhibits the development of mammary carcinogenesis and are consistent with a recent report from the Nurses Health Study that bean or lentil intake is associated with a lower risk for breast cancer. ${ }^{111}$

\section{Peristrophe bicalyculata}

The oil of $P$. bicalyculata (Acanthaceae) displayed in vitro cytotoxicity $(2.5-22.3 \mu \mathrm{g} / \mathrm{ml}$ ) to MCF-7 (human breast tumor) and MDA-MB-468 (human breast tumor) cells. With respect to the oil of $P$. bicalyculata, beta-caryophyllene (33.9\%), alpha-zingiberene (10.4\%), germacrene D and globulol (5.0\%) were the compounds occurring in abundance. ${ }^{112}$

\section{Phyllanthus rheedii}

The alcohol (95\%) extract of the whole plant of Phyllanthus rheedii (Euphorbiaceae) has the antitumoral activity on lung carcinoma cell lines (A549), colon carcinoma cell lines (HCT-116), liver carcinoma cell lines (HEPG-2) and cervical carcinoma cell lines (HELA). The HELA cells were treated with $5 \mathrm{mg} / \mathrm{ml}$ and the remarkable inhibition of cells were found. The water extract of $P$. urinaria did not exert any cytotoxic effect on normal cells such as endothelial cells and liver cells. The anticancer activity of $P$. urinaria extract was due to the apoptosis induced in Lewis lung carcinoma cells (LLC), which was demonstrated by DNA fragmentation analysis and increased caspase- 3 activity. The apoptosis triggered by $P$. urinaria extract in Lewis lung carcinoma cells was associated with the down-regulation of $\mathrm{Bcl}-2$ gene expression. $\mathrm{IC}_{50}$ value of $P$. urinaria extract on LLC cells was determined to be $2 \mathrm{mg} / \mathrm{ml}$. $P$. urinaria inhibited human osteosarcoma 143B cells growth through an apoptotic extrinsic pathway to activate Fas receptor/ligand expression. Mitochondria is essential for the anticancer mechanism induced by $P$. urinaria through upregulation of $\mathrm{Bid}, \mathrm{tBid}$, and $\mathrm{Bax}$ and downregulation of $\mathrm{Bcl}-2$, both extrinsic and intrinsic pathways. The acting ingredients in P. urinaria that exerted the anticancer effect may include polyphenols such as ellagic acid, flavanoids or tanins, which are abundant in P. urinaria. Gallic acid and ellagic acid were supposed to be the most effective compounds in the $P$. urinaria to induce the cytotoxic effect of NPC-BM1 cells. Apoptosis of osteosarcoma 143B cells was also triggered by $P$. urinaria. Geraniin, quercetin $3-\beta$-d-glucopyranoside, kaempferol 3 - $\beta$-dglucopyranoside, isocorilagin, quercetin, kaempferol and rutin showed the strong antiproliferative activity. ${ }^{113-114}$ 


\section{Paris polyphylla}

Eight compounds were obtained from Paris polyphalla (Trilliaceae) and identified as Falcarindiol, $\beta$-ecdysterone and six known saponins. The dry rhizomes $(5 \mathrm{~kg}$ ) of $P$. polyphylla were refluxed three times with $70 \%$ $\mathrm{EtOH}$ (10L each) for 6 hours to afford ethanolic extract. $\beta$-ecdysterone and three pennogenin steroidal saponins were isolated from the EtOH extract of $P$. polyphylla, and then tested for their antitumor against HepG2 cells, with $\mathrm{IC}_{50}$ values of $13.5 \mu \mathrm{M}, 9.7 \mu \mathrm{M}$ and $11.6 \mu \mathrm{M}$ respectively. The antitumor activity of steroid saponins of $P$. polyphylla against lung adenocarcinoma cells was found. The tumor weight in all treated groups was significantly lower than that in the control group and the inhibition of tumor growth were $41.82 \%, 29.44 \%$, and $33.94 \%$ in their high-dose groups. Extract of P. polyphylla (PPE) inhibited the proliferation of SMMC-7721 cells dose- and time-dependently. By $S$ phase cell cycle arrest, the activation of pro-caspase 3 , and a marked increase in $\mathrm{Bax} / \mathrm{Bcl}-2$ ratios due to upregulation of Bax and downregulation of $\mathrm{Bcl}-2$ proteins expression. A new spirostanol steroidal saponin, along with ten known saponins, which were based upon (25R)-spirost-5-en-3 $\beta$-o1 (diosgenin) or (25R)-spirost-5-ene-3 $\beta 5,17 \alpha$-diol (pennogenin) as the aglycones, were isolated from the rhizomes of $P$. polyphylla var. chinensis. The isolated saponins were evaluated for their cytotoxic activity on human promyelocytic leukemia HL-60 cells. It was found that treatment of MCF-7 and MDA-MB-231 cells with polyphyllin D resulted with an $\mathrm{IC}_{50}$ of $5 \mu \mathrm{M}$ and $2.5 \mu \mathrm{M}$, respectively, in the inhibition of viability and induction of apoptosis in a dose-dependent manner, by inducing a downregulation of anti-apoptotic Bcl-2 expression and an up-regulation of pro-apoptotic Bax expression, and activates caspase-9. A novel steroidal saponin, along with 12 known steroidal compounds, was isolated from the rhizomes of $P$. polyphylla var. chinensis. Spectral data, including twodimensional NMR, showed that the structure of the novel saponin was 3b, 21-dihydroxypregnane-5-en-20S-(22,16)-lactone-1-O-a-L-rhamnopyranosyl (12)-[b- D-xylopyranosyl(1-3)]-b-D-glucopyranoside. The isolated steroidal compounds were evaluated for their cytotoxic activity on human gastric cancer cell line HepG2, SGC7901, BxPC3. Diosgenyl3-O-a-Lrhamnopyranosyl (12) [a-L-arabinofuranosyl(1-4)]-b-D-glucopyranoside (polyphyllin D) exhibited the most potent cytotoxic activity among the isolated steroids. PD exhibits the cell-killing mechanisms of this compound in R-HepG2 and its parental cells elicit programmed cell death via mitochondrial dysfunction. ${ }^{115-117}$

\section{Platycodon grandiflorum}

Petroleum ether extract from Platycodon grandiflorum (Campanulaceae) was evaluated using human cancer cell lines (HT-29, HRT-18 and HepG2). P. grandiflorum can reduce the extent of a lung metastasis of B16-F10 melanoma cells by inhibiting the adhesion of tumor cells to the basement membrane possibly and activating NK cells. The inhibitory effects of CKS on MMP-2 and MMP-9 activation, relation of tumor invasion and migration in vitro possibly involve mechanisms related to its ability to suppress PMA-enhanced NF- $\kappa \mathrm{B}$ activation through ROS signaling pathway. Aqueous extract from the root of Platycodon grandiflorum (AEPG) was studied for the cell growth and apoptosis in human lung carcinoma cell line A549. Exposure of A549 cells to AEPG resulted in growth inhibition and induction of apoptosis in a dose-dependent manner with a decrease in Bcl-2 expression, an increase of Bax and an activation of caspase-3. AEPG treatment markedly inhibited the activity of telomerase in a dose-dependent fashion. Platycodon D is a major constituent of triterpene saponins found in the root of Platycodon grandiflorum, evaluated the association of these effects with apoptotic tumor cell death using a human leukemic U937 cell line. The apoptotic effects of crude saponins acquired from the roots of $P$. grandiflorum (SPR) in HT-29 human colon cancer cells revealed that SPR decreased HT-29 cell proliferation, by inducing apoptosis via DNA fragmentation and activation of initiator caspases- 8 and -9 , as well as the effector caspase-3. ${ }^{118,119}$

\section{Plumbago zeylanica}

Plumbagin (5-hydroxy-2-methyl-1, 4-naphthoquinone) from Plumbago zeylanica (Plumbaginaceae) may have potential as an antitumor agent by releasing of mitochondrial cytochrome $c$ and apoptosis inducing factor (AIF), thus activation of caspase-dependent and -independent pathways, as shown by the plumbagin-mediated activation of caspase- 3 and -9. Plumbagin exhibited cell proliferation inhibition by inducing cells to undergo $\mathrm{G}_{2}-\mathrm{M}$ arrest and autophagic cell death. Blockade of the cell cycle was associated with increased p21/WAF1 expression and Chk2 activation, and reduced amounts of cyclin B1, cyclin A, Cdc2, and Cdc25C. Plumbagin also reduced Cdc2 function by increasing the association of $\mathrm{p} 21 / \mathrm{WAF} 1 / \mathrm{Cdc} 2$ complex. The reducing effect of plumbagin treatment on viability of human prostate cancer cells (PC-3, LNCaP, and C4-2) with apoptosis induction, which was accompanied by ROS generation and depletion of intracellular GSH levels. Plumbagin inhibited the growth of Panc-1 and Bxpc-3 cells in a dose-dependent and time-dependent manner. Exposure to plumbagin caused the upregulation of Bax, a rapid decline in mitochondrial transmembrane potential, apoptosis-inducing factor overexpression in cytosol, and the cleavage of procaspase- 9 and poly ADP-ribose polymerase. It has potential antiproliferative activity against human non-small lung epithelium carcinoma cells (A549) and indicated that the IC50 value for plumbagin is $14.6 \mu \mathrm{M}$. It is known to possess anticancer in human promyelocytic leukemia cells, NB4, by the mitochondrial pathway. With the increase of the concentrations of plumbagin there is extention of action time, thus the inhibitory action on tongue cancer cell proliferation would be more obvious. Tumor necrosis factor-related apoptosis-inducing ligand (TRAIL) is a promising anti-cancer agent. Plumbagin enhances TRAILmediated apoptosis through up-regulation of death receptor in human melanoma A375 Cells. It activates ERK1/2 and inhibit Akt activity in cancer cells. It activates $\mathrm{NAD}(\mathrm{P}) \mathrm{H}$ oxidase, Src, and PI3K, and that the activated PI3K or PDK1 subsequently stimulate Akt and RasRaf-MEK1/2-ERK1/2 in 3T3-L1 cells. The anti-proliferative and apoptotic activity of plumbagin by using two human colonic cancer cell lines, HT29 and HCT15 showed the $\mathrm{IC}_{50}$ of Plumbagin for HCT15 and HT29 cells ( $22.5 \mu \mathrm{M}$ and $62.5 \mu \mathrm{M}$, respectively) were significantly different through activation of NFKB, Caspases-3, elevated levels of TNF- $\alpha$, cytosolic Cytochrome C were seen in both HCT15 cells HT29 treated with plumbagin, aberrant apoptosis with decreased level of pEGFR, pAkt, pGsk-3 $\beta$, PCNA and Cyclin D1was observed only in $15 \mu \mathrm{M}$ and $30 \mu \mathrm{M}$ plumbagin treated HCT15 and $75 \mu \mathrm{M}$ plumbagin treated HT29 cells. It has been used to inhibit ultraviolet radiation (UVR)-induced development of squamous cell carcinomas (SCC). It $(5-20 \mu \mathrm{mol} / \mathrm{L})$ induces apoptosis of SGC-7901 cells, and potentiated the sensitivity of SGC-7901 cells to chemotherapeutic agents TNF- $\alpha$ and cisplatin. The naphthoquinones, juglone and plumbagin, could be promising chemopreventive agents for human intestinal neoplasia. ${ }^{120-122}$

\section{Piper nigrum}

Six alkaloids Piperine, piperidine, piperettine, piperanine, piperlongumine and piperlonguminine extracted from Piper nigrum (Piperaceae) sample showed antiproliferative activity against several human cancer cell lines. The incubation of tumor cell lines with 5-FU in the presence of piplartine or piperine produced an increase in tumor growth inhibition and significantly lowered in lung-cancer bearing mice and B16F-10 melanoma cells. The alkaloid piperdine was purified by refluxion method to check the antitumour activity which shows $51.38 \%$ of inhibition at $5 \mu \mathrm{g} / \mathrm{ml}$ concentration. Oral supplementation of piperine $(50 \mathrm{mg} / \mathrm{kg}$ body weight) effectively suppressed lung carcinogenesis. Piperine, 
guineensine, pipericide, $\mathrm{N}$-feruloyltyramine and $\mathrm{N}$-isobutyl-2E, $4 E$-dodecadienamide were isolated from a crude chloroform extract of $P$. nigrum and have effect on melanocyte proliferation. The effect of piperine on mitochondrial tricarboxylic acid cycle and phase I and glutathione-metabolizing enzymes in Benzo(a)pyrene induced experimental lung carcinogenesis in swiss albino mice showed a significant decrease in the activities of mitochondrial enzymes-isocitrate dehydrogenase $(\mathrm{ICDH})$, ketoglutarate dehydrogenase $(\mathrm{KDH})$, succinate dehydrogenase $(\mathrm{SDH})$, malate dehydrogenase $(\mathrm{MDH})$ and significantly increased NADPH-Cytochorome reductase (NADPH-C reductase), cytochrome P450 (cyt-p450) and cytochrome b5(cyt-b5). The activities of glutathionemetabolizing enzymes glutathione peroxidase (GPx), glutathione reductase (GR) and glucose-6-phospho dehydrogenase (G6PDH) were significantly lowered in lung-cancer bearing mice when compared with control mice. Piperine supplementation to tumour-induced animals significantly lowered the phase-I enzymes (NADPH-C reductase, cyt-p450 and cyt-b5) and there was a rise in glutathione-metabolizing enzymes (GPx, GR and G6PDH), which indicated an antitumour and anti-cancer effect. ${ }^{123,124}$

\section{Perilla frutescens}

The methanolic extracts from different parts of Perilla frutescens (Lamiaceae were evaluated for their antiproliferative activities by using human non-small cell lung A549 cancer cells. The methanolic extract of stalk exhibited moderate antiproliferative activity. Stalk of $P$. frutescens might be used as a potential source of potential source of natural antioxidants and as an anti-tumor agent. The hot water extract of stalk showed moderate DPPH radical scavenging abilities of $54.8 \%$ at $10 \mu \mathrm{g} / \mathrm{ml}$, whereas those of leaf and seed scavenged DPPH radicals by 5.5 and $6.7 \%$ at $10 \mu \mathrm{g} / \mathrm{ml}$, respectively. The phytochemicals, polyphenols and flavanoids are responsible for the anticarcinogenic activity. ${ }^{125}$

\section{Rhizophora apiculata}

Rhizophora apiculata (Rhizophoraceae) extract of whole plant was found to protect mice from cyclophosphamide (CTX) induced leukopenia. The leukocyte counts in the $R$. apiculata extract treated animals was significantly increased $\left(10425 \pm 163 \mathrm{~mm}^{3}\right)$ whereas the control group shows no significant increase $\left(7855 \pm 282 \mathrm{~mm}^{3}\right)$. Moreover, $R$. apiculata extract prevented the loss of organ weight and increased the organ weight in treated animals. ${ }^{126}$

\section{Rubia cordifoli}

The powdered roots of Rubia cordifolia (Rubiaceae) was percolated with $80 \%$ methanol to obtain the methanol extract. Several secondary plant metabolites and four new naphthohydroquinones and two naphthohydroquinone dimmers were isolated from roots of $R$. cordifolia was investigated for the COX-2 inhibitory activity which may serve as lead molecules for cancer chemoprevention studies. The novel antitumor bicyclic hexapeptides RA-VI, VIII, RA-XV, XVI and RA-XVII were isolated from the roots of $R$. cordifolia. RA-IX and -X, new antitumour bicyclic hexapeptides were isolated from $R$. cordifolia containing a glutamic acid at residue showed strong antitumour activity. RA-XI, -XII, XIII and -XIV were isolated from $R$. cordifolia and showed potent antitumor activities against P-388. ${ }^{127}$

\section{Radix sophorae}

Leachianone A, isolated from Radix Sophorae (Leguminosae), possesses cytotoxic activity against human hepatoma cell line HepG2 in vitro via induction of apoptosis involved both extrinsic and intrinsic pathways, with an $\mathrm{IC}_{50}$ value of $3.4 \mu \mathrm{g} / \mathrm{ml} 48 \mathrm{~h}$ post treatment. The root extract of Radix Sophorae induced apoptosis in human hepatoma HepG2 cells via the intrinsic mitochondrial death pathway, depletion and generation of ROS in cells, which subsequently led to mitochondrial dysfunction and apoptosis. ${ }^{128}$

\section{Rosmarinus officinalis}

Oral administration of Rosmarinus officinalis (Lamiaceae) leaves extrac, stage induced by 7,12-dimethylbenzanthracene (DMBA), reduced the tumor burden percent incidence of mice bearing papillomas to $41.66 \%$. A significant decrease was observed in Lipid peroxidation level by the administration of ROE. Reduced glutathione (GSH) and total proteins was found to be significantly elevated in liver and skin of mice in ROE treated group. Skin and liver of $R$. officinalis treated group animals showed a significant enhancement in antioxidant enzymes like superoxide dismutase (SOD) and Catalase, when compared with the carcinogen treated control. These studies indicate that $R$. officinalis could reduce the chemical induced tumor and oxidative stress during skin carcinogenesis. ROE had inhibitory effect on the proliferation of A549 and SMMC7721, the effect was dose dependent. The inhibitory rate was $(93.06 \pm 1.56 \%)$ and $(84.39 \pm 1.96 \%)$, respectively for A549 and SMMC7721 at $48 \mathrm{~h}$ at the concentration of $200 \mathrm{mg} / \mathrm{mL}$. R. officinalis extract was studied for antiproliferation activity against human ovarian cancer cells, and whether the extract and its three main active ingredients, carnosol (CS), carnosic acid (CA) and rosmarinic acid (RA) can enhance the antiproliferation activity of cisplatin (CDDP). It has significant antiproliferation activity on human ovarian cancer A2780 and its CDDP resistant daughter cell line A2780CP70. Extracts of leaves of $R$. officinalis and the active compounds, carnosic acid, and rosmarinic acid were applied to various human cancer cell lines including NCI-H82 (human, small cell lung, carcinoma), DU-145 (human, prostate, carcinoma), Hep-3B (human, black, liver, carcinoma, hepatocellular), K-562 (human chronic myeloid leukemia), MCF-7 (human, breast, adenocarcinoma), PC-3 (human, prostate, adenocarcinoma) and MDA-MB-231 (human, breast, adenocarcinoma). ${ }^{129-131}$

\section{Saussurea lappa}

The dried roots of Saussurea lappa (Asteraceae) were investigated for the anticancer constituents from the hexane extract of this plant, a new sesquiterpene was isolated along with the known compounds costunolide, $\beta$-cyclocostunolide, dihydro costunolide and dehydro costuslactone having anticancer active isolates and its derivatives were studied. Three components cynaropicrin (1), reynosin (2), and santamarine (3) were isolated from the methanol extract of $S$. lappa radix stem bark showed potent inhibitory effect on the production of tumor necrosis factor- $\alpha$ (TNF- $\alpha$ ), a proinflammatory cytokine, in murine macrophage-like cell (RAW264.7 cells). The molar concentrations of cynaropicrin, reynosin, and santamarine producing $50 \%$ inhibition $\left(\mathrm{IC}_{50}\right.$ ) of TNF- $\alpha$ production were $2.86 \mu \mathrm{g} / \mathrm{ml}(8.24 \mu \mathrm{M}), 21.7 \mu \mathrm{g} / \mathrm{ml}(87.4 \mu \mathrm{M})$, and $26.2 \mu \mathrm{g} / \mathrm{ml}$ $(105 \mu \mathrm{M})$, respectively. The effects of $S$. lappa on proliferation and expression of cell growth/apoptosis related molecules, with using an AGS gastric cancer cell line showed induced apoptotic cell death of AGS. S. lappa induce growth inhibition and apoptosis of human gastric cancer cells, with down- and up-regulation of growth-regulating apoptotic and tumor suppressor genes, respectively. Sesquiterpenes found in the extract showed anticancer activity. ${ }^{132,133}$

\section{Tylophora indica}

Tylophorine was extracted from the leaves of regenerated plants using organic solvents such as like hexane, chloroform and dichloromethane and separated on high performance thin layer chromatography (HPTLC) using toluene: chloroform: ethanol: ammonia (4:3.5:1.5:drop) as mobile phase. Amount of tylophorine obtained was 80 and $71 \mu \mathrm{g} / \mathrm{ml}$ from callus raised and directly cultured in vitro plants respectively. PBT-1 suppressed Akt activation accelerated RelA degradation via I $\mathrm{B}$ kinase- $\mathrm{R}$ and down-regulated NF- $\mathrm{BB}$ target gene expression. C9-Substituted phenanthrene-based tylophorine derivatives (PBTs) were synthesized and evaluated as in vitro anticancer agents against the human A549 lung 
cancer cell line. Twelve active compounds were further examined against DU-145 (prostate), ZR-751 (breast), KB (nasopharyngeal), and KB-Vin (multidrug resistant KB subline) human cancer cell lines. They showed potent cytotoxic activity against both wild type and matched multidrug resistant KB cell lines, and displayed notable selectivity toward DU-145 (prostate) and ZR-751 (breast) cancer cell lines. Tylophorine and its analogs are phenanthroindolizidine alkaloids, several of which have been isolated from the Tylophora genus. All four tylophorine analogs exerted potent growth-inhibitory effects against HepG2, a human hepatocellular carcinoma cell line, and $\mathrm{KB}$, a human nasopharyngeal carcinoma cell line. ${ }^{134}$

\section{Taraxacum officinale}

The ethylacetate, butanol, methanol and cold water extracts of the plant had significantly higher radical scavenging (\%) and total phenolic contents than the hot water, and hexane extracts. Cytotoxic effects of all the extracts evaluated using the SRB assay on HeLa, HT-29, HepG2 and $\mathrm{KB}$ cell lines demonstrated that the ethylacetate extract with an $\mathrm{IC}_{50}$ of $15.5 \mu \mathrm{g} / \mathrm{ml}$ was potentially very toxic against human mouth epidermal carcinoma (KB) than all other extracts. Effect of Taraxacum officinale (Asteraceae) (TO) on the cytotoxicity and production of cytokines in human hepatoma cell line, Hep G2 decreased the cell viability by $26 \%$, and significantly increased the tumor necrosis factor (TNF)- $\alpha$ and interleukin (IL)-1a production compared with media control (about 1.6-fold for TNF- $\alpha$, and 2.4 -fold for IL-1 $\alpha, \mathrm{P}<0.05$ ). TO strongly induced apoptosis of Hep G2 cells as determined by flow cytometry. Increased amounts of TNF- $\alpha$ and IL- $1 \alpha$ contributed to TO-induced apoptosis. These results suggest that TO induces cytotoxicity through TNF- $\alpha$ and IL- $1 \alpha$ secretion in Hep G2 cells. ${ }^{135}$

\section{Taxus yunnanensis}

The extract of roots of $T$. yunnanensis (Taxaceae) showed that they were rich in taxane diterpenoids, including paclitaxel and dihalocephalomannine with anticancer property. Two new taxane diterpenes, dantaxusin $\mathrm{C}$ and dantaxusin $\mathrm{D}$ were isolated from an ethanol extract of the aerial parts of Taxus yunnanensis along with 14 known taxoids. Twelve taxane diterpenes, which were isolated previously from the EtOH extract of the aerial parts of T. yunnanensis or T. chinensis, were evaluated for cytotoxicity against the multidrug resistant cancer cells KB-VIN and KB-7d. Seven taxane diterpenes were isolated from the EtOH extract of the aerial parts of $T$. chinensis, and evaluated for cytotoxicity against nine human cell lines, including a $\beta$-tublin mutant resistant to paclitaxel. Taxane-type diterpenes, such as 10-deacetyl cephalomannine and 10-deacetyltaxol, were found in wood extract of T. yunnanensis and present in amounts consistent with the growth inhibitory activity. Diterpenes showed remarkable antiproliferative activity. ${ }^{136}$

\section{Tabebuia avellanedae}

Callus and cell suspension cultures of Tabebuia avellanedae (Bignoniaceae) produced promising antitumour-promoting furanonaphthoquinones, 5-hydroxy-2-(1-hydroxyethyl)naphtha [2,3-b]furan-4,9-dione and 2-acetyl-5-hydroxy-naphtho[2,3-b]furan-4,9-dione in high yields. A series of naphthoquinones based on the naphtho[2,3-b]furan-4,9dione skeleton such as (-)-5-hydroxy-2-(1'-hydoxyethyl)naphtha [2,3-b]furan-4,9-dione) and its positional isomer, (-)-8-hydroxy-2(1'-hydoxyethyl)naphtho[2,3-b]furan-4,9-dione, which are secondary metabolites found in the inner bark of Tabebuia avellanedae, were synthesized and their biological activities such as antiproliferative and cancer chemopreventive activity were examined. The effects of Tabebuia avellanedae crude extract (TACE), traditionally prescribed in the treatment of cancer, and the naphtoquinone $\beta$-lapachone ( $\beta$-lap) on the growth and differentiation of granulocyte and macrophage progenitor cells (CFU-GM) were studied in Ehrlich ascites tumour-bearing mice. $\beta$-lapachone exerts its anti-proliferative action in cultured human prostate carcinoma DU145 cells. Exposure of DU145 cells to $\beta$-lapachone resulted in growth inhibition and induction of apoptosis in a dosedependent manner. ${ }^{137,138}$

\section{Vaccinium macrocarpon}

Triterpene cinnamates 3-O-p-hydroxycinnamoyl ursolic acid purified from the ethyl acetate extracts of Vaccinium macrosporan (Ericaceae) showed slightly greater activity of compound in most tumor cell lines, with $\mathrm{GI}_{50}$ values of approximately $20 \mu \mathrm{M}$ in MCF-7 breast, ME180 cervical and PC3 prostate tumor cell lines. Antiproliferative activities of isolated compounds from cranberries extract against HepG2 human liver cancer and MCF-7 human breast cancer cells were evaluated. Among the compounds isolated, ursolic acid, quercetin, and 3,5,7,3',4'-pentahydroxyflavonol-3-O-beta-D-glucopyranoside showed potent antiproliferative activities against HepG2 cell growth, with $\mathrm{EC}_{50}$ values of $87.4 \pm$ $2.7,40.9 \pm 1.1$, and $49.2 \pm 4.9 \mu \mathrm{M}$, respectively. ${ }^{139,140}$

\section{ACKNOWLEDGEMENT}

Authors are thankful to Banasthali University and Guru Ghasidas Vishwavidyalaya for providing the facilities to carry out the research.

\section{CONFLICT OF INTEREST}

The author declare no conflict of interest.

\section{ABBREVIATION USED}

QOL: Quality of life; EEAV: Ethanolic extract of A. venustum Don; AMS: Abelmoschus moschatus seed; AML: Abelmoschus moschatus leaf; DPPH: 1,1-Diphenyl-2-picrylhydrazyl; CHD: Crude dicloromethane extract; CHE: Crude hydroalcoholic extract; AS: Alangium salviifolium; EAC: Ehrlich Ascites Carcinoma; GSH: reduced glutathione; GST: glutathione-S-transferase; GR: glutathione reductase; LPO: Lipid peroxidation; BUN: Blood urea nitrogen; GPx: Glutathione peroxidise; ODC: Ornithine decarboxylase; AMR: Amooranin; AME: Aegle marmelos; TNF- $\alpha$ : Tumor necrosis factor alpha; DEN: Diethylnitrosamine; 2-AAF: 2-acetyl aminofluorene; OSCs: Organosulfur compounds; ROS: Reactive oxygen species; SAMC: S-allylmercaptocysteine; MEAS: Methanolic extract of Allium sativum; SLs: Sesquiterpene lactones; MAPK: Mitogen-activated protein kinases; DLA: Dalton's lymphoma ascites; AEBS: Aqueous extract of Biophytum sensitivum; DAL: Dalton's Ascitic Lymphoma; LPS: Lipopolysaccharide; MECB: Methanol extract of Caesalpinia bonducella; SOD: Superoxide dismutase; CAT: Catalase; AA: Asiatic acid; siRNA: Small interfering RNA; CJ: Cirsium japonicum; HHT: Homoharringtonine; CA: cinnamaldeyde; MPD: Methyl protodioscin; DL: Daltons lymphoma; NDEA: N-nitrosodiethylamine; OCs: Osteoclastogenesis; MAA: Mollic acid arabinoside; MAX: Mollic acid xyloside; RA: Tannic acid; AML: Acute myeloid leukemia; AAL: Acute lymphoblastic leukemia; MMP: Matrix metalloproteinase; DMBA: 7,12 dimethylbenz(a) anthracene; ERa: Estrogen receptor alpha; OA: Oleanolic acid; UA: Ursolic acid; SA: Stearic acid; LUT7G: Luteolin-7-O-glucoside; LLC: Lewis lung carcinoma; MNNG: N-methyl N'-nitro-N-nitrosoguanidine; AIF: Apoptosis inducing factor; SCC: Squamous cell carcinomas; ICDH: Isocitrate dehydrogenase; KDH: Ketoglutarate dehydrogenase; SDH: succinate dehydrogenase; MDH: Malate dehydrogenase; G6PDH: Glucose-6-phospho dehydrogenase; CTX: cyclophosphamide; RA: Rosmarinic acid; HPTLC: High performance thin layer chromatography; PBTs: Phenanthrene-based tylophorine derivatives. 


\section{REFERENCES}

1. American Cancer Society. Cancer Facts \& Figures. Atlanta: American Cancer Society; 2010.

2. Boivin JF. Second Cancers and Other Late Side Effects of Cancer Treatment. Cancer 1990;65(S3):770-5

3. Yates JS, Mustian KM, Morrow GR, Gillies LJ, Padmanaban D, Atkins JN, Issell B, Kirshner JJ, Colman LK. Prevalence of complementary and alternative medicine use in cancer patients during treatment. Support Care Cancer. 2005; 13(10):806-11.

4. Sri PU, Sree NV, Revathi S, Kumar YVVA, Sri ND. Role of herbal medicines in cancer. Int J Pharm Sci Res. 2010;1(11):7-21.

5. Devmurari VP, Pandey S, Goyani MB, Jivani NP, Marotrao S, Sivakumar P Evaluation of Anticancer Activity of Adiantum venustum (Don). Int J Pharmacog Phy Res. 2010;2(1):5-10

6. Mubashir S, Shah WA. Phytochemical and Pharmacological Review Profile of Adiantum venustum. Int J Pharm Tech Res. 2011;3(2):827-30.

7. Gul MZ, Bhakshu LM, Ahmad F, Kondapi AK, Qureshi IA, Ghazi IA. Evaluation of Abelmoschus moschatus extracts for antioxidant, free radical scavenging, antimicrobial and antiproliferative activities using in vitro assays. BMC Complement Altern Med. 2011;11(1):64

8. Kohn LK, Pizao PE, Foglio MA, Antonio MA, Amaral MCE, Bittric V et al. Antiproliferative activity of crude extract and fractions obtained from Aspido-sperma tomentosum Mart. Rev Bras PI Med Botucatu. 2006;8(esp):110-5.

9. Andrea L, Holguin MF, Holguin O, Micheletto S, Goehle S, Julian A, Mary A Connell O. Chemotypic Variation of Essential Oils in the Medicinal Plant Anemopsis californica. Phytochemistry. 2008;69(4):919-27.

10. Catherine N, Seth KL, Lowrey T, Guerra L, Slambrouck SV, Wim FA. In vitro anticancer activity of Anemopsis californica. Oncol Lett. 2010;1(4):711-15

11. Childs RF, Cole JR. Phytochemical and pharmacological investigation of Anemopsis californica. J Pharm Sci. 1965;54(5):789-91.

12. Laizuman N, Ronok Z, Ashik M, Saiful I, Anamul H, Abul F, Mele J. Antioxidant and antitumor activity of chloroform extract of Alangium salvifolium flowers. Phytopharmacol. 2012;2(1):123-34

13. Ronok Z, Badrul AM, Saiful IM, Gopal SC, Nargis CS, Salman HB, Mosaddik MA, Mele J Ekramul HM. Anticancer activity of Alangium salvifolium flower in Ehrlich ascites carcinoma bearing mice. J Cancer Res. 2011;7(3):254-62

14. Sharma AK, Agarwal V, Kumar R, Balasubramaniam A, Mishra A, Gupta R Pharmacological studies on seeds of Alangium salvifolium linn. Acta Poloniae Pharmaceutica Drug Res. 2011;68(6):897-904.

15. Prasad L, Khan TH, Tamanna J, Sarwat S. Acorus calamus extracts and nicke chloride, prevention of oxidative damage and hyperproliferation response in rat kidney. Biol Trace Elem Res. 2006;113(1):77-91.

16. Rajkumar V, Guha G, Kumar AR, Mathew L. Evaluation of cytotoxic potential of Acorus calamus rhizome. Ethnobotanical Leaflets. 2009;13:832-9.

17. Gyawali R, Kim K. Volatile organic compounds of medicinal values from Nepalese Acorus calamus. J Sci Engg Tech. 2009;5(2):51-65.

18. Palani S, Raja S, Kumar RP, Venkdesan D, Devi K, Sivaraj A, Senthil BK. Therepeutic efficacy of antihepatotoxic and antioxidandt activities of Acorus calamus on acetaminophen- induced toxicity in rats. Int J Integr Biol. 2009;7(1):39-44

19. Singh, R, Sharma, PK, Rishabha M. Pharmacological Properties and ayurvedic value of Indian buch plant (Acorus calamus): A Short Review. Adv Biol Res. 2011;5(3):145-54.

20. Kuete V, Vouffo B, Mbaveng AT, Vouffo EY, Siagat RM, Dongo E. Evaluation of Antiaris africana methanol extract and compounds for antioxidant and antitumor activities. Pharm Biol. 2009;47(11):1042-9.

21. Vouffo B, Etienne D, Petrea F, Andrea T, George S, Armin M, et al. Antiaroyl cinnamate and africanoside, a cinnamoyl triterpene and a hydroperoxy-cardenolide from the stem bark of Antiaris Africana. Planta Medica. 2010;76(15):1717-23.

22. Rabi T, Karunagaran D, Nair MK, Bhattathiri VN. Cytotoxic activity of amooranin and its derivatives. Phytother Res. 2002;16(S1):84-6

23. Rabi T, Liming W, Banerjee S. Novel triterpenoid 25-hydroxy-3-oxoolean-12en-28-oic acid induces growth arrest and apoptosis in breast cancer cells. Breast Cancer Res Treat. 2007;101(1):27-36.

24. Rabi T, Ramachandran C, Fonseca HB, Nair RPK, Alamo A, Melnick SJ, Escalon E. Novel drug amooranin induces apoptosis through caspase activity in human breast carcinoma cell lines. Breast Cancer Res Treat. 2003;80(3):321-30.

25. Chan LL, Sherine G, Irfan A, Saujanya GL, Atiya A, Cunningham BT, Watkin $\mathrm{KL}$. Cytotoxicity effects of Amoora rohituka and chittagonga on Breast and Pancreatic Cancer Cells. Evid Based Complement Alternat Med. 2011; Article ID 860605, 8 pages.

26. Cheppail R, Thangaiyan R, Fonseca HB, Steven MJ, Enrique AE. Novel plant triterpenoid drug amooranin overcomes multidrug resistance in human leukemia and colon carcinoma cell lines. Int J Cancer. 2003;105(6):784-9

27. RabiT, Banerjee S. Novel semisynthetic triterpenoid AMR-Me inhibits telomerase activity in human leukemic CEM cells and exhibits in vivo antitumor activity against Dalton's lymphoma ascites tumor. Cancer Lett. 2009;278(2):156-63.

28. Thangapazham RL, Singh AK, Seth P, Misra N, Mathad VT, Raj K, et al. Shikonin analogue (SA) 93/637 induces apoptosis by activation of caspase-3 in U937 cells. Front Biosci. 2008;13:561-8.

29. Bibi Y, Nisa S, Zia M, Waheed A, Ahmed S, Chaudhary MF. Adenocarcinoma Cell Line (MCF-7) and phytochemical analysis. Pak J Pharm Sci. 2012;25(1):183-7.

30. Zhang Z, Li S, Lian XY. An overview of genus aesculus L.: Ethnobotany, Phytochemistry, and Pharmacological activities. Pharm Crops. 2010;1:24-51.

31. Jagetia GC, Venkatesh P, Baliga MS. Aegle marmelos (L.) Correa Inhibits the Proliferation of Transplanted Ehrlich Ascites Carcinoma in Mice. Biol Pharm Bull. 2005;28(1):58-64.

32. Lampronti ID, Martello N, Bianchi M, Borgatti E, Lambertini R, Piva S, et al. In vitro antiproliferative effects on human tumor cell lines of extracts from the Bangladeshi medicinal plant Aegle marmelos Correa. Phytomedicine. 2003; 10(4):300-8

33. Gangadevi $\vee$, Muthumary J. Taxol, an anticancer drug produced by an endophytic fungus Bartalinia robillardoides Tassi, isolated from a medicinal plant, Aegle marmelos Correa ex Roxb. World J Microbiol Biotechnol. 2008;24(5):717-24.

34. Subramaniam D, Giridharan P, Murmu N, Shankaranarayanan NP, May R, Houchen CW, et al. Activation of Apoptosis by 1-Hydroxy-5,7-Dimethoxy2-Naphthalene Carboxaldehyde, a Novel Compound from Aegle marmelos. Cancer Res. 2008;68(20):8573-81.

35. Khan TH, Sultana S. Effect of Aegle marmelos on DEN initiated and 2-AAF promoted hepatocarcinogenesis: a chemopreventive study. Toxicol Mech Methods. 2011:21(6):453-62

36. Islam MS, Kusumoto Y, Al-Mamun MA. Cytotoxicity and Cancer (HeLa) Cel Killing Efficacy of Aqueous Garlic (Allium sativum) Extract. J Sci Res. 2011:3(2):375-82.

37. Thomson M, Ali M. Garlic [Allium sativum]: a review of its potential use as an anti-cancer agent. Curr Cancer Drug Targets. 2003;3(1):67-81.

38. Karmakar S, Choudhury SR, Banik NL, Swapan RK. Molecular Mechanisms of Anti-cancer Action of Garlic Compounds in Neuroblastoma. Anticancer Agents Med Chem. 2011:11(4):398-407.

39. Shukla Y, Kalra N. Cancer chemoprevention with garlic and its constituents. Cancer Lett. 2007;247(2):167-81.

40. Guruvayoorappan C, Kuttan G. Immunomodulatory and antitumor activity of Biophytum sensitivum extract. Asian Pacific J Cancer Prev. 2007;8(1):27-32.

41. Bhaskar VH, Rajalakshmi V. Anti-tumor activity of aqueous extract of Biophytum sensitivum Linn. Annals Biol Res. 2010;1(3):76-80.

42. Guruvayoorappan C. Apoptotic Effect of Biophytum sensitivum on B16F-10 Cells and Its Regulatory Effects on Nitric Oxide and Cytokine Production on TumorAssociated Macrophages. Integr Cancer Ther. 2007;6(4):373-80.

43. Guruvayoorappan C. Biophytum sensitivum (L.) DC Inhibits Tumor Cell Invasion and Metastasis Through a Mechanism Involving Regulation of MMPs, Proly Hydroxylase, Lysyl Oxidase, nm23, ERK-1, ERK-2, STAT-1, and Proinflammatory Cytokine Gene Expression in Metastatic Lung Tissue. Integr Cancer Ther. 2008;7(1):42-50.

44. Cichewicz RH, Kouzi SA. Chemistry, biological activity, and chemotherapeutic potential of betulinic acid for the prevention and treatment of cancer and HIV infection. Med Res Rev. 2004;24(1):90-114.

45. Chatterjee D, Sahu RK, Jha AK, Dwivedi J. Evaluation of Antitumor Activity of Cuscuta Reflexa Roxb (Cuscutaceae) Against Ehrlich Ascites Carcinoma in Swiss Albino Mice. Trop J Pharm Res. 2011;10(4):447-54.

46. Suresh V, Sruthi $V$, Padmaja B, Asha VV. In vitro anti-inflammatory and anticancer activities of Cuscuta reflexa Roxb. J Ethnopharmacol. 2011;134(3):872-7.

47. Gupta M, Mazumder UK, Kumar RS, Sivakumar T, Vamsi ML. Antitumor activity and antioxidant status of Caesalpinia bonducella against Ehrlich ascites carcinoma in Swiss albino mice. J Pharmacol Sci. 2004:94(2):177-84.

48. Gupta M, Mazumder UK, Rath N, Mukhopadhyay DK. Antitumor activity of methanolic extract of Cassia fistula L seed against Ehrlich Ascites Carcinoma. J Ethnopharmacol. 2000;72(1):151-6.

49. Rejiya CS, Cibin TR, Annie A. Leaves of Cassia tora as a novel cancer therapeutic-An in vitro study. Toxicol in Vitro. 2009;23(6):1034-8.

50. Bala A, Kar B, Pallab KH, Mazumdar UK, Bera S. Evaluation of anticancer activity of Cleome gynandra Ehrlich Ascites Carcinoma treated mice. J Ethnopharmacol. 2010;129(1):131-4

51. Chul PB, Kefa BO, Eung-Seok L, Soo LY, Jung-Ae K. Asiatic Acid Induces Apoptosis in SK-MEL-2 Human Melanoma Cells. Cancer Lett. 2005;218(1):81-90

52. Cho CW, Choi DS, Cardone MH, Kim CW, Sinskey AJ, Rha C. Glioblastoma cell death induced by asiatic acid. Cell Biol Toxicol. 2006;22(6):393-408.

53. Heidari M, Heidari-Vala H, Sadeghi MR, Akhondi MM. The inductive effects of Centella asiatica on rat spermatogenic cell apoptosis in vivo. J Nat Med. 2012;66(2):271-8.

54. Rai N, Agrawal RC, Khan A. Chemopreventive Potential of Centella asiatica on B6F10 Melanoma Cell Lines in Experimental Mice. Pharmacologyonline $2011 ; 1: 748-58$

55. Suboj B, Jose P, Priya PS, Vinod V, Karedath AAT, Priya S, Srinivas G. Apoptosis Induction of Centella Asiatica on Human Breast Cancer Cells. Afr J Trad Complement Altern Med. 2009;6(1):9-16.

56. Susi E, Jaksa S, Marsiati H, Fauziah O, Rahmat A. Effects of cola nut (Cola 
nitida) on the apoptotic cell of human breast carcinoma cell lines. J Med Plants Res. 2011;5(11):2393-7.

57. Liu S, Luo X, Li D, Zhang J, Qiu D, Liu W, She L, Yang Z. Tumor inhibition and improved immunity in mice treated with flavone from Cirsium japonicum DC. Int Immunopharmacol. 2006;6(9):1387-93.

58. Liu S, Zhang J, Li D, Liu W, Luo X, Zhang R, Li L, Zhao J. Anticancer activity and quantitative analysis of flavone of Cirsium japonicum DC. Nat Prod Res. 2007;21(10):915-22.

59. Yin $Y$, Heo S, Wang MH. Antioxidant and Anticancer Activities of Methanol and Water Extracts from Leaves of Cirsium japonicum. J Appl Biol Chem. 2008;51(4):160-4

60. Jin Y, Lu Z, Cao K, ZhuY, Chen Q, Zhu F, Qian C, Pan J. The Antitumor Activity of Homoharringtonine against Human Mast Cells Harboring the KIT D816V Mutation. Mol Cancer Ther. 2010;9(1):211-23.

61. Meng H, Yang C, Jin J, Zhou Y, Qian W. Homoharringtonine inhibits the AKT pathway and induces in vitro and in vivo cytotoxicity in human multiple myeloma cells. Leuk Lymphoma. 2008;49(10):1954-62.

62. Ni D, Ho DH, Vijjeswarapu M, Felix E, Rhea PR, Newman RA. Metabolism of homoharringtonine, a cytotoxic component of the evergreen plant Cephalotaxus harringtonia. J Exp Ther Oncol. 2003;3(1):47-52.

63. Bakshi HA, Sam S, Anna F, Zeinab R, Ahmad SG, Sharma M. Crocin from Kashmiri Saffron (Crocus sativus) Induces in Vitro and in Vivo Xenograft Growth Inhibition of Dalton's Lymphoma (DLA) in Mice. Asian Pacific J Cancer Prev. 2009;10(5):887-90.

64. Fikrat Al. Cancer Chemopreventive and Tumoricidal Properties of Saffron (Crocus sativus L.). Exp Biol Med. 2002;227(1):20-5

65. Kumar PK. Protective effect of saffron (Crocus sativus L.) aqueous extract against genetic damage induced by anti-tumor agents in mice. Hum Exp Toxicol. 2006:25(2):79-84

66. Gomez-Flores R, Martínez HH, Guerra PT, Guerra RT, Licea RQ, Enriqueta CM, Padilla CR. Antitumor and immunomodulating potential of Coriandrum sativum, Piper nigrum and Cinnamomum zeylanicum. J Nat Prod. 2010;3:54-63.

67. Huang TC, Fu HY, Ho CT, Tan D, Huang YT, Pan MH. Induction of apoptosis by cinnamaldehyde from indigenous cinnamon Cinnamomum osmophloeum Kaneh through reactive oxygen species production, glutathione depletion, and caspase activation in human leukemia K562 cells. Food Chem. 2007;103(2):434-43.

68. Singh R, Koppikar SJ, Paul P, Gilda S, Paradkar AR, Ghanekar RK. Comparative analysis of cytotoxic effect of aqueous cinnamon extract from Cinnamomum zeylanicum bark with commercial cinnamaldehyde on various cell lines. Pharm Biol. 2009;47(12):1174-9.

69. Koppikar SJ, Choudhari AS, Suryavanshi SA, Kumari S, Chattopadhyay S, Kaul-Ghanekar R. Aqueous Cinnamon Extract (ACE-C) from the bark of Cinnamomum cassia causes apoptosis in human cervical cancer cell line $(\mathrm{SiHa})$ through loss of mitochondrial membrane potential. BMC Cancer. 2010;10(1):210.

70. Csupor-Loffler B, Hajdu Z, Zupko I, Molnar J, Forgo P, Vasas A, Kele Z, Hohmann J. Antiproliferative Constituents of the Roots of Conyza Canadensis. Planta Medica. 2011;77(11):1183-8.

71. Maneerat W, Tha-in S, Cheenpracha S, Prawat U, Laphookhieo S. New amides from the seeds of Clausana lansium. J Med Plants Res. 2011;5:2812-5.

72. Prasad KN, Hao J, Yi C, Zhang D, Qiu S, Jiang Y, Zhang M, Chen F. Antioxidant and Anticancer Activities of Wampee (Clausena lansium (Lour.) Skeels) Peel. J Biomed Biotech. 2009; Article ID 612805, 6 pages.

73. Motta FCM, Santos DYAC, Salatino MLF, Almeida JMD, Negri G, Carvalho JE, Ruiz ALTG, Ines C, Salatino A. Constituents and antiproliferative activity of extracts from leaves of Croton macrobothrys. Rev bras farmacogn. 2011:21(6):972-7.

74. Wang $X, X u$ J, Yang $M$, Hong Z. Chloroform extract of Tibetan herbal medicine Dracocephalum tanguticum Maxim. inhibits proliferation of T98G glioblastomas cells by modulating Caspase-3 cleavage and expression of Bax and p21. J Med Plants Res. 2011;5(25):6024-31.

75. Hu M, Xu L, Yin L, Qi Y, Li H, Xu Y, Han X, Peng J, Wan X. Cytotoxicity of dioscin in human gastric carcinoma cells through death receptor and mitochondria pathways. J Appl Toxicol. 2011;33(8):712-22.

76. Wang G, Chen H, Huang M, Wang N, Zhang J, Zhang Y, Bai G, Fong WF, Yang M, Yao X. Methyl protodioscin induces G2/M cell cycle arrest and apoptosis in HepG2 liver cancer cells. Cancer Lett. 2006;241(1):102-9.

77. Cibin TR, Srinivas G, Gayathri DD, Priya S, Lija Y, Annie A. Antioxidant and Antiproliferative Effects of Flavonoids from Emilia sonchifolia Linn on Human Cancer Cells. Int J Pharmacol. 2006:2(5):520-4.

78. Sidambaram RR, Dinesh MG, Jayalakshmi ET. An in Vitro Study of Cytotoxic Activity of Euphorbia Hirta on Hep2 Cells of Human Epithelioma of Larynx. Int J Pharm Pharm Sci. 2011:3(Supple 3):101-3.

79. Guo Z, XuY, Han L, Bo X, Huang C, Ni L. Antioxidant and cytotoxic activity of the acetone extracts of root of Euphorbia hylonoma and its ellagic acid derivatives, J Med Plant Res. 2011;5(23):5584-9

80. Baliga MS, Dsouza JJ. Amla (Emblica officinalis Gaertn), a wonder berry in the treatment and prevention of cancer. Eur J Cancer Prev. 2011;20(3):225-39.

81. Poojari R, Gupta S, Maru G, Khade B, Bhagwat S. Chemopreventive and Hepatoprotective Effects of Embelin on N-Nitrosodiethylamine and Carbon
Tetrachloride Induced Preneoplasia and Toxicity in Rat Liver. Asian Pac J Cancer Prev. 2010;11(4):1015-20.

82. Yang CJ, Wang CS, Hung JY, Huang HW, Chia YC, Wang PH, Weng CF, Huang MS. Pyrogallol induces G2-M arrest in human lung cancer cells and inhibits tumor growth in an animal model. Lung Cancer. 2009;66(2):162-8.

83. Balijepalli MK, Tandra S, Pichika MR. Antiproliferative activity and induction of apoptosis in estrogen receptor-positive and negative human breast carcinoma cell lines by Gmelina asiatica roots. Pharmacog Res. 2010;2(2):113-9.

84. Noudeh GD, Sharififar F, Noodeh AD, Moshafi MH, Afzadi MA, Behravan E, et al. Antitumor and antibacterial activity of four fractions from Heracleum persicum Desf. and Cinnamomum zeylanicum Blume. J Med Plants Res. 2010:4(21):2176-80

85. Lam SK, Ng TB. Novel galactonic acid-binding hexameric lectin from Hibiscus mutabilis seeds with antiproliferative and potent HIV-1 reverse transcriptase inhibitory activities. Acta Biochimica Polonica. 2009;56(4):649-54.

86. Lin CC, Kuo CL, Lee MH, Hsu SC, Huang AC, Tang NY, Lin JP, Yang JS, Lu CC Chiang JH, Chueh FS, Chung JG. Extract of Hedyotis diffusa Willd Influences Murine Leukemia WEHI-3 Cells in vivo as well as Promoting T- and B-Cell Proliferation in Leukemic Mice. In vivo. 2011;25(4):633-40.

87. Shao J, Gong G, Trombetta L. An Evidence-based Perspective of Hedyotis Diffusa or Oldenlandia Diffusa (Spreading Hedyotis) for Cancer Patients. Evidencebased Anticancer Complementary and Alternative Medicine, Evidence-based Anticancer Materia Medica. 2011;179-92.

88. Wang JH, Shu LH, Yang LL, Meng Z, Ping H. 2-Hydroxy-3-methylanthraquinone from Hedyotis diffusa Wild Induces Apoptosis via Alteration of Fas/FasL and Activation of Caspase-8 in Human Leukemic THP-1 Cells. Archive Med Res. 2011;42(7):577-83

89. Kumar RS, Rajkapoor B, Perumal P. Antitumor and Cytotoxic Activities of Methanol Extract of Indigofera linnaei Ali, Asian Pacific J Cancer Prev. 2011;12(3):613-8.

90. Wong YH, Abdul KH, Ling SK. Bioassay-Guided Isolation of Cytotoxic Cycloartane Triterpenoid Glycosides from the Traditionally Used Medicinal Plant Leea indica. eCAM. 2012; 2012: Article ID 164689, 11 pages.

91. Raihan MO, Tareq SM, Brishti A, Alam MK, Haque A, Ali MS. Evaluation of Antitumor Activity of Leea indica (Burm.f.) Merr. Extract against Ehrlich Ascites Carcinoma (EAC) Bearing Mice. Am J Biomed Sci. 2012;4(4):143-52.

92. Wang L, Xu GF, Liu XX, Chang AX, Xu ML, Ghimeray AK, Piao JP, Cho DH In vitro antioxidant properties and induced G2/M arrest in HT-29 cells of dichloromethane fraction from Liriodendron tulipifera. J Med Plants Res. 2012;6(3):424-32

93. Moon MK, Oh HM, Kwon BM, Baek NI, Kim SH, Kim JS, Dae Keun Kim DK. A Farnesyl Protein Transferase and Tumor Cell Growth Inhibitory Activities of Lipiferolide Isolated from Liriodendron tulipifera. Arch Pharm Res. 2007;30(3):299-302.

94. Bhoopat L, Srichairatanakool S, Kanjanapothi D, Taesotikul T, Thananchai H, Bhoopat T. Hepatoprotective effects of lychee (Litchi chinensis Sonn.): A combination of antioxidant and anti-apoptotic activities. J Ethnopharmacol. 2011;136(1):55-66

95. Roya S, Besraa SE, Deb T, Banerjeec B, Mukherjeed J, Vedasiromoni JR Induction of Apoptosis in Human Leukemic Cell Lines U937, K562 and HL-60 by Litchi chinensis Leaf Extract Via Activation of Mitochondria. Mediated Caspase Cascades. Open Leukemia J. 2008;1(1):1-14.

96. Guevara AP, Vargas C. Anti-inflammatory and antitumor activities of seed extracts of malunggay, Moringa oleifera L. (Moringaceae). Philippine J Sci. 1996;125(issue??):175-84

97. Khalafalla MM, Abdellatef E, Dafalla HM, Nassrallah AA, Aboul-Enein KM, Lightfoot DA, El-Deeb FE, El-Shemy HA. Active principle from Moringa oleifera Lam leaves effective against two leukemias and a hepatocarcinoma. African $J$ Biotech. 2010;9(49):8467-71

98. Khalafalla MM, Abdellatef E, Dafalla HM, Nassrallah AA, Aboul-Enein KM, Hany A, El-Shemy HA, Abdellatef E. Dedifferentiation of leaf explants and antileukemia activity of an ethanolic extract of cell cultures of Moringa oleifera. African J Biotech. 2011;10(14):2746-50.

99. Lee SJ, Cho YH, Park K, Kim EJ, Kang BS, Jung KH, Kim CH, Kim WJ, Moon SK. Inhibitory effects of the aqueous extract of Magnolia officinalis on the responses of human urinary bladder cancer 5637 cells in vitro and mouse urinary bladder tumors induced by $\mathrm{N}$-Butyl-N-(4-hydroxybutyl) nitrosamine in vivo. Phytother Res. 2009;23(1):20-7.

100. Romeilah RM. Anticancer and antioxidant activities of Matricaria chamomilla L. and Marjorana hortensis essential oils. Res J Medicine Medical Sci. 2009:4(2):332-9.

101. Sharma V. A polyphenolic compound rottlerin demonstrates significant in vitro cytotoxicity against human cancer cell lines: isolation and characterization from the fruits of Mallotus philippinensis. J Plant Biochem Biotechnol. 2011;20(2):190-5.

102. Yanga MY, Changa YC, Chanb KC, Leec YJ, Wanga CJ. Flavonoid-enriched extracts from Nelumbo nucifera leaves inhibits proliferation of breast cancer in vitro and in vivo. Eur J Integr Med. 2011;3(3):e153-63

103. Zhang X, Liu Z, Xu B, Sun Z, Gong Y, Neferine CS. An alkaloid ingredient in lotus seed embryo inhibits proliferation of human osteosarcoma cells by promoting p38 MAPK-mediated p21 stabilization. Eur J Pharmacol. 2012;677(1):47-54 
104. Kohli KR, Nipanikar SU, Kadbhane KP. A Comprehensive Review on Trivrit [Operculina Turpethum Syn. Ipomoea Turpethum]. Int J Pharma Bio Sci. 2010;1(4):443-52

105. Fan HW, Min H, Li YU, Yan LI, Ying-bin LI. Study on the Anti-tumor effect of Oldenlandia diffusa on HL60 and B16BL6 cell line in vitro. Chinese J Hospital Pharm. 2009;20.

106. Wu PK, Chi Shing, Tai W, Liang ZT, Zhao ZZ, Hsiao WL. Oleanolic acid isolated from Oldenlandia diffusa exhibits a unique growth inhibitory effect against ras-transformed fibroblasts. Life Sci. 2009;85(3):113-21.

107. Islam MS, Akhtar MM, Rahman MM, Rahman MA, Sarker KK, Alam MF. Antitumor and Phytotoxic Activities of leaf methanol extract of Oldenlandia diffusa (Willd.) Roxb. Global J Pharmacol. 2009;3(2):99-106.

108. Raveendran VV, Vijayan FP, Padikkala J. Antitumor Activities of an Anthraquinone Fraction Isolated from in Vitro Cultures of Ophiorrhiza rugosa var decumbens. Integr Cancer Ther. 2012;12(2):120-8.

109. Pattanayak $P$, Behera $P$, Das D, Panda SK. Ocimum sanctum Linn. A reservoir plant for therapeutic applications: An overview. Pharmacogn Rev. 2010;4(7):95105.

110. Rastogi S, Shukla Y, Paul BN, Chowdhuri DK, Khanna SK, Das M. Protective effect of Ocimum sanctum on 3-methylcholanthrene, 7,12-dimethylbenz(a) anthracene and aflatoxin B1 induced skin tumorigenesis in mice. Toxicol Appl Pharmacol. 2007;224(3):228-40.

111. Thompson MD, Thompson HJ, Brick MA, McGinley JN, Jiang W, Zhu Z, Wolfe P. Mechanisms Associated with Dose-Dependent Inhibition of Rat Mammary Carcinogenesis by Dry Bean (Phaseolus vulgaris, L.). J Nutr. 2008;138(11):2091-7.

112. Ogunwande IA, Walker TM, Bansal A, Setzer WN, Essien EE. Essential oil constituents and biological activities of Peristrophe bicalyculata and Borreria verticillata. Nat Prod Commun. 2010;5(11):1815-8.

113. Sivajothi V, Leelaprakash G. Cytotoxicity Screening of Alcoholic Extract of the Whole Plant of Phyllanthus rheedii. Res J Chem Env. 2010;14(3):81-2

114. Wu HY, Lin TK, Kuo HM, Huang YL, Liou CW, Wang PW, Chuang JH, Huang ST. Phyllanthus urinaria Induces Apoptosis in Human Osteosarcoma 143B Cells via Activation of Fas/FasL- and Mitochondria-Mediated Pathways. eCAM. 2012; 2012: Article ID 925824, 13 pages.

115. Gao LL, Li FR, Jiao P, Yang MF, Zhou XJ, Si YH, Jiang WJ, Zheng TT. Paris chinensis dioscin induces $\mathrm{G} 2 / \mathrm{M}$ cell cycle arrest and apoptosis in human gastric cancer SGC-7901 cells. World J Gastroenterol. 2011;17(39):4389-95.

116. Sun J, Liu BR, Wei J, Qian XP, Yu LX, Guo RH, Shen H, Wang TS. The extract of Paris polyphylla exerts apoptotic induction and synergic antiproliferative effect with anticancer drugs in SMMC-7721 human liver cancer cells. Biomed Prev Nutr. 2011;1(3):186-94.

117. Yun H, Lijian C, Wenhong Z, Yuhong D, Yongli W, Qiang W, Ding Z. Separation And Identification Of Steroidal Compounds With Cytotoxic Activity Against Human Gastric Cancer Cell Lines In Vitro From The Rhizomes of Paris polyphylla VAR. chinensis. Chem Nat Comp. 2007;43(6):672-7.

118. Lee KJ, Hwang SJ, Choi JH, Jeong HG. Saponins derived from the roots of Platycodon grandiflorum inhibit HT-1080 cell invasion and MMPs activities: Regulation of NF-KB activation via ROS signal pathway. Cancer Lett. 2008;268(2):233-43

119. Shin DY, Kim GY, Li W, Choi BT, Kim ND, Kang HS, Choi YH. Implication of intracellular ROS formation, caspase-3 activation and Egr-1 induction in platycodon D-induced apoptosis of U937 human leukemia cells. Biomed Pharmacother. 2009;63(2):86-94.

120. Checker R, Sharma D, Sandur SK, Subrahmanyam G, Krishnan S, Poduval TB, Sainis KB. Plumbagin inhibits proliferative and inflammatory responses of $T$ cells independent of ROS generation but by modulating intracellular thiols. $J$ Cell Biochem. 2010;110(5):1082-93.

121. Chen CA, Chang HH, Kao CY, Tsai TH, Chen YJ. Plumbagin, Isolated from Plumbago zeylanica, Induces Cell Death through Apoptosis in Human Pancreatic Cancer Cells. Pancreatology. 2009;9(6):797-809.

122. Powolny AA, Singh SV. Plumbagin-induced Apoptosis in Human Prostate Cancer Cells is Associated with Modulation of Cellular Redox Status and Generation of
Reactive Oxygen Species. Pharm Res. 2008;25(9):2171-80.

123. LiuY, Yadev VR, Aggarwal BB, Nair MG. Inhibitory effects of black pepper (Piper nigrum) extracts and compounds on human tumor cell proliferation, cyclooxygenase enzymes, lipid peroxidation and nuclear transcription factor-kappa-B. Nat Prod Commun. 2010;5(8):1253-7.

124. Reshmi SK, Sathya E, Suganya PD. Isolation of piperdine from Piper nigrum and its antiproliferative activity. J Pharm Res. 2010;3(10):2502-7.

125. Lin ES, Chou JH, Kuo PL, Huang YC. Antioxidant and antiproliferative activities of methanolic extracts of Perilla frutescens. J Med Plants Res. 2010;4(6):47783

126. Vinod PV, Guruvayoorappan C. Evaluation of immunostimulant activity and chemoprotective effect of mangrove Rhizophora apiculata against cyclophosphamide induced toxicity in BALB/c mice. Immunopharmacol Immunotoxicol. 2012;34(4):608-15.

127. Patel P, Nagar A, Patel R, Rathod D, Patel V. In vitro Anticancer Activity of Rubia Cordifolia against Hela and Hep2 Cell Lines. Int J Pharm Pharm Sci. 2011;3(2):70-1.

128. Long G, Wang G, Ye L, Lin B, Wei D, Liu L, Yang L. Important Role of TNF- $\alpha$ in Inhibitory Effects of Radix Sophorae flavescentis Extract on Vascular Restenosis in a Rat Carotid Model of Balloon Dilatation Injury. Planta Medica. 2009;75(12):1293-9

129. Parmar J, Sharma P, Verma P, Sharma P, Goyal PK. Anti-tumor and Anti-oxidative Activity of Rosmarinus officinalis in 7, 12 Dimethyl Benz (a) Anthracene Induced Skin Carcinogenesis in Mice. Am J Biomed Sci. 2011;3(3):199-209.

130. Tai J, Cheung S, Wu M, Hasman D. Antiproliferation effect of Rosemary (Rosmarinus officinalis) on human ovarian cancer cells in vitro. Phytomedicine 2012;19(5):436-43.

131. Tsai CW, Lin CY, Lin HH, Chen JH. Carnosic Acid, a Rosemary Phenolic Compound, Induces Apoptosis Through Reactive Oxygen Species-Mediated p38 Activation in Human Neuroblastoma IMR-32 Cells. Neurochem Res. $2011 ; 36(12): 2442-51$.

132. Kim EJ, Lim SS, Park SY, Shin HK, Kim JS, Park JH. Apoptosis of DU145 human prostate cancer cells induced by dehydrocostus lactone isolated from the root of Saussurea lappa. Food Chem Toxicol. 2008;46(12):3651-8.

133. Robinson A, Kumar TV, Sreedhar E, Naidu VG, Krishna SR, Babu KS, Srinivas PV, Rao JM. A new sesquiterpene lactone from the roots of Saussurea lappa: Structure-anticancer activity study. Bioorg Med Chem Lett. 2008:18(14):4015-7.

134. Anand HK, Goyal D. Extraction of tylophorine from in vitro raised Manju plants of Tylophora indica. J Med Plants Res. 2011;5(5):729-34

135. Sigstedt SC, Hooten CJ, Callewaert MC, Jenkins AR, Romero AE, Pullin MJ, Kornienko A, Lowrey TK, Slambrouck SV, Steelant WF. Evaluation of Aqueous Extracts of Taraxacum Officinale on Growth and Invasion of Breast and Prostate Cancer Cells. Int J Oncol. 2008;32(5):1085-90.

136. Shinozaki $Y$, Fukamiya $N$, Fukushima $M$, Okano $M$, Nehira $T$, Tagahara $K$, Zhang SX, Zhang DC, Lee KH. Dantaxusins C and D, Two Novel Taxoids from Taxus yunnanensis. J Nat Prod. 2002;65(3):371-4

137. Queiroz ML, Valadares $M C$, Torello CO, Ramos AL, Oliveira AB, Rocha FD, Arruda VA, Accorci WR. Comparative studies of the effects of Tabebuia avellanedae bark extract and $\beta$-lapachone on the hematopoietic response of tumourbearing mice. J Ethnopharmacol. 2008;117(2):228-35.

138. Yamashita $M$, Kaneko $M$, Tokuda $H$, Nishimura $K$, Kumeda $Y$, lida A. Synthesis and evaluation of bioactive naphthoquinones from the Brazilian medicinal plant Tabebuia avellanedae. Bioorg Med Chem. 2009;17(17):6286-91.

139. He X, Liu RH. Cranberry phytochemicals: Isolation, structure elucidation, and their antiproliferative and antioxidant activities. J Agric Food Chem. 2006;54(19):7069-74.

140. Kondo M, MacKinnon SL, Craft CC, Matchett MD, Hurta RA, Neto CC. Ursolic acid and its esters: occurrence in cranberries and other Vaccinium fruit and effects on matrix metalloproteinase activity in DU145 prostate tumor cells. J Sci Food Agric. 2011;91(5):789-96.

\section{SUMMARY}

- The article describes the significance of herbal drugs in the treatment of cancer and is a brief compilation of the anticancer potential of medicinal plants viz. Adiantum venusutum, Abelmoschus moschatus, Aspidosperma tomentosum, Anemopsis californica, Alangium salviifolium, Acorus calamus, Antiaris Africana, Amoora rohituka, Arnebia nobilis, Aesculus hippocastanum, Aegle marmelos, Allium sativum, Biophytum sensitivum, Betula utilis, Cuscuta reflexa, Caesalpinia bonducella, Cassia fistula, Cassia tora, Cleome gynandra, Centella asiatica, Cola nitida, Cirsium japonicum, Cephalotaxus harringtonia, Crocus sativus, Cinnamomum zeylanicum, Conyza canadensis, Clausena lansium, Croton macrobotrys, Dracocephalum tanguticum, Dioscorea collettii, Emilia sonchifolia, Euphorbia hirta, Emblica officinalis, Gmelina asiatica, Heracleum persicum, Hibiscus mutabilis, Hedyotis diffusa, Indigofera linnaei, Leea indica, Liriodendron tulipifera, Litchi chinensis, Moringa oliefera, Magnolia sieboldii, Matricaria chamomilla, Mallotus philippinensis, Nelumbo nucifera, Operculina turpethum, Oldenlandia diffusa, Ophiorrhiza mungos, Ocimum sanctum, Phaseolus vulgaris, Peristrophe bicalyculata, Phyllanthus rheedii, Paris polyphylla, Platycodon grandiflorum, Plumbago zeylanica, Piper nigrum, Perilla frutescens, Rhizophora apiculata, Rubia cordifolia, Radix sophorae, Rosmarinus officinalis, Saussurea lappa, Tylophora indica, Taraxacum officinale, Taxus yunnanensis, Tabebuia avellanedae, and Vaccinium macrocarpon. 


\section{PICTORIAL ABSTRACT}

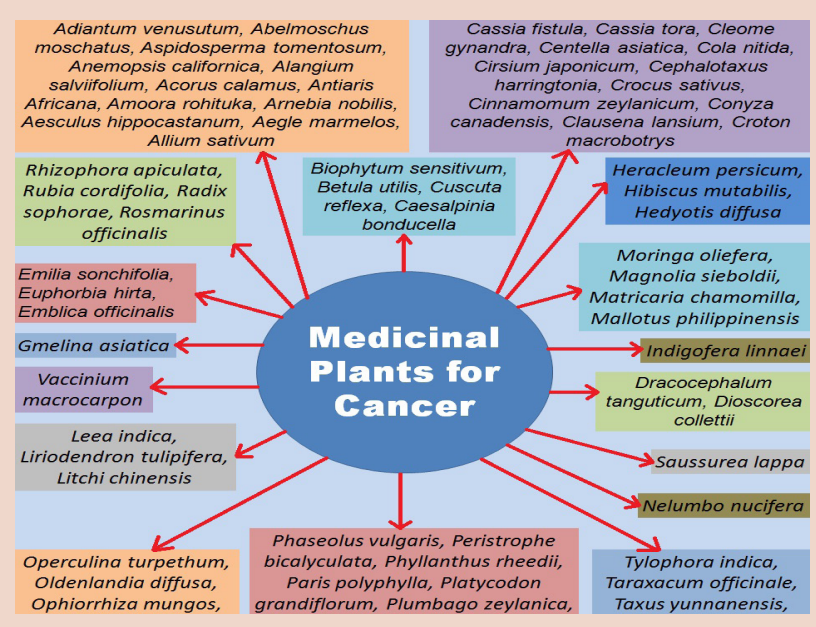

\section{ABOUT AUTHORS}

Arjun Patra: Obtained his M. Pharm. and Ph.D. degree from Birla Institute of Technology, Mesra, Ranchi, India. Currently he is working as Assistant Professor at Institute of Pharmaceutical Sciences, Guru Ghasidas Vishwavidyalaya, Bilaspur, Chhattisgarh, India. Dr. Patra's research involves novel methods of extraction of botanicals to enhance yield of bioactive compounds and exploration of Medicinal Plants for antidiabetic, antiosteoporetic, anticancer, adaptogenic and antimicrobial activities.

Dr. Sonika Jain: Assistant Professor, Department of Chemistry, Banasthali Unuversity-Rajasthan-304022. She has completed her research work from Banasthali University in 2011. Her area of specialization is medicinal chemistry, natural product exploration, organic chemistry. She is life member of Indian Science congress.

Dr. Jaya Dwivedi: Associate Professor and Head Department of Chemistry at Banasthali University, Banasthali, Rajasthan, and Ph.D. (Chemistry-2003) from Guru Ghasidas University, Bilaspur. She has 16 years of teaching experience. Till date 10 students have been awarded under her supervision and currently 8 are working. Her area of research includes Exploration of Medicinal Plants for antidiabetic, anticancer, and antimicrobial activitiy \& Synthesis of medicinally potent molecules and their pharmacological evaluation. She is life member of Indian Science Congress and Indian Chemical society. 